\title{
THE RUSTLE OF GHOSTS: BUNG KARNO IN THE NEW ORDER'
}

\author{
Karen Brooks
}

\section{Introduction}

In the final days of September 1994, a polemic erupted in the Indonesian press over a new book written by eighty-year-old journalist and former Nationalist Party of Indonesia (PNI) leader, Manai Sophiaan. The book, according to the author, is an attempt to clarify former President Sukarno's position in the events before, during, and after the tragic coup attempt on September 30, 1965 (hereafter referred to by the Indonesian acronym G-30-S). The author's position on this matter is quite clear from the start: the book's title reads Kehormatan Bagi Yang Berhak: Bung Karno Tidak Terlibat G-30-S (Respect for Him Who Deserves It: Bung ${ }^{2}$ Karno Was Not Involved in G-30-S). Several weeks later, on September 25 , following the publication of a lengthy interview with the author in the magazine, Tiara, ${ }^{3}$ Manai Sophiaan and his new book became the subject of a fierce national debate.

In the now notorious interview with Tiara, as well as other subsequent interviews, Manai declared that he wrote the book in order to "straighten out history" - to make sure that Sukarno is accorded the respect and historical role that he deserves. ${ }^{4}$ As the book's title suggests, Manai is arguing that Sukarno was not involved in the coup. But given that the Soeharto government has never directly implicated him in the coup, for whom was Manai making his historical clarification? In the twenty-four years since Sukarno's death, President Soeharto has officially recognized Sukarno as a national hero, made his gravesite a national monument, given Sukarno's name to the country's largest international airport, and built an

\footnotetext{
${ }^{1}$ This paper was originally submitted to Benedict Anderson on December 8, 1994 as part of course work at Cornell University. My sincerest thanks to Benedict Anderson and Audrey and George Kahin for their comments and support. Thanks also to Ben Abel, Saya Shiraishi, Lawton Bloom, and Lorraine Paterson for encouraging my first creation at Cornell. Responsibility for translations lies solely with the author.

2 "Bung" is a familiar term of address meaning "brother" that was popular in the Old Order. The term fell into disfavor in the New Order and has been replaced by the term "Bapak" or father. "Bung Karno" is thus the popular name for Sukarno.

3 "Bung Karno Tidak Terlibat," Tiara, October 27, 1994.

4 "Saya Hanya meluruskan Sejarah," Forum Keadilan, October 27, 1994, p. 32.
} 
Independence Monument with Sukarno's statue in Jakarta. So against what forces did this eighty-year-old man feel compelled to protect Sukarno's good name?

More intriguing yet, how can one explain the excessively dramatic and protracted polemic that unfolded in the press in the wake of his book's release? Sukarno's family, government ministers, former and current student activists, artists, writers, and professors have actively taken part in the debate. Why have people from such a wide range of professions, experiences, and political ideologies felt compelled to support or criticize this old man's book? And why are people so angry? Sukmawati Sukarnoputri (Sukarno's daughter) is suing writer Mochtar Lubis for comments he made in reference to Manai's book. Two different organizations of former student activists plan to sue Manai Sophiaan. Manai Sophiaan is considering suing Tiara. And the Supreme Court is considering requests that the book be banned and the polemic stopped. Manai's book is just one of many dealing with Bung Karno and the 1965 coup. So why the commotion? And why now, in 1994?

Just as the storm around Manai Sophiaan and his book was raging, the government released its long awaited Buku Putih (White Book) on the traumatic events of 1965. This is not actually the first White Book on the coup that has been prepared by the government. In 1978, a White Book written by Nugroho Notosusanto, then Central Head of ABRI's (Armed Forces of the Republic of Indonesia's) Military History, was distributed among a limited circle of government officials but never released to the public..$^{5}$ Rumors have since circulated that the government was on the verge of publishing its official account, though sixteen years passed after Nugroho's original White Book was written before the government actually did so. According to Minister of the State Secretariat (Mensesneg) Moerdiono, who led the government compiling team, the book, entitled G-30-S: Pembrontakan Partai Komunis Indonesia-Latar Belakang, Aksi dan Penumpasannya (The 30th of September Movement: The Rebellion of the Communist Party of Indonesia-Its Background, Action and Annihilation) was written so that the debate regarding the coup could finally be put to rest. ${ }^{6}$ But instead of calming the waters that were stirred by Manai Sophiaan, the Buku Putih seems to have stirred up controversies of its own. Many openly questioned the government's motives in publishing such a book-why publish a White Book twenty-nine years after the coup took place? What are the political motives? Others questioned the government's ability to write a historical text, stating that such an enterprise should have been undertaken by a more objective body. Some in the government suddenly found themselves wondering why after years of calling for a White Book on the coup, many Indonesians now thought the project was a bad idea. 7

In reexamining the coup attempt and Bung Karno's role in the affair, both Manai and the government are, of course, opening old wounds. In the nearly thirty years since that watershed event, there has been a great deal of disagreement over many details of the coup and its aftermath. Despite the abundance of literature on the subject, the intricacies of the roles played by different actors in the drama remain, at best, controversial-and none more so than that of President Sukarno himself. The official government and ABRI interpretation

5 "Tambal Sulam Sejarah Si Bung," Sinar, June 20, 1994, p. 19; "Dari Buku Putih Sampai Cornell Paper" Tempo, October 6, 1990, p. 29.

6 "Saya Tidak Berani Menghukum Bung Karno," Forum Keadilan, October 27, 1994, p. 21.

${ }^{7}$ In an interview with Forum Keadilan on October 27, 1994, Moerdiono was asked if he had considered the fact that the publication of the Buku Putih would open old wounds. He responded by saying, "You are funny. When I hadn't yet released a White Book, you came after me. Now, after I've published a Buku Putih, you're saying that I'm opening old wounds. What's the deal?" Ibid. 
has been that the PKI (the Indonesian Communist Party) was behind the coup attempt. ${ }^{8}$ This rendition of events has been fed to the Indonesian people since the army crushed the coup in 1965 and continues to be propagandized via the government film which has been aired every September 30 since 1982. However, within the film, as within other statements emanating from the government, Bung Karno's role in the coup has remained ambiguous. The rest of the world has hardly been in agreement with the New Order interpretation, nor has it come to any meaningful consensus on Sukarno's role. Some foreign observers have written that the coup attempt was essentially an internal power struggle within the army. ${ }^{9}$ These works have been banned in Indonesia on the grounds of "obscuring historical fact," though anyone who follows the periodic polemics in the press can read at least summaries of the opinions expressed in these works. ${ }^{10}$ Others have implied that Sukarno himself was the mastermind of the coup. ${ }^{11}$ One of the books that asserts this conclusion, Anthonie C. A. Dake's The Devious Dalang, was banned in Indonesia in 1990 after sixteen years in publication.

Opinion, then, has remained divided. But it is clear that Soeharto's New Order government, having been born of the coup and the ensuing national chaos, has a definite interest in preserving its official version of events and its role within them-i.e. that the PKI was behind an insidious plot to wrest control of the government and that ABRI, united under Major-General Soeharto's command, quashed the coup and punished the usurpers. Much of New Order legitimacy rests on the acceptance of this interpretation, so any reopening of the record is bound to ruffle government feathers. Thus, in what seems to have been an effort to prevent that record from being reopened, the government restated its official position in the form of a White Book. Before the White Book's release, many Indonesian journalists and pundits expressed the hope that the Buku Putih, using previously unreleased testimony from the trials of the G-30-S leaders, would settle the lingering issue of Sukarno's involvement once and for all. However, for reasons that will be discussed later, neither Sukarno's supporters nor detractors are entirely satisfied with the final product. The controversy, it seems, will go on.

Any discussion of the coup inevitably gives way to a broader discussion of Sukarno himself. Indeed the fiery nationalist who struggled against the Dutch and led Indonesia to independence left a great mark on the nation he helped found. He stood up to the West, snubbing the UN and telling the United States to "go to hell" with its aid in response to American support for the newly established Malaysian federation. With an extraordinary ability to connect with the masses, Sukarno empowered young Indonesia with the strength of his own persona. His charisma, his charm and his legendary oratorical prowess make him a natural target for romantic reflection in today's Indonesia. Not everyone, to be sure, speaks glowingly of Sukarno today, nor did everyone praise him in his day. As his loss of

8 See Nugroho Notosusanto and Ismail Saleh, The Coup Attempt of the September 30 Movement in Indonesia, (Jakarta: Pembimbing Masa, 1968); Guy Pauker, The Rise and Fall of the Communist Party in Indonesia (Santa Monica: The Rand Corp., 1969) and Arnold Brackman, The Communist Collapse in Indonesia (New York: Norton, 1969).

${ }^{9}$ See Benedict R. Anderson and Ruth McVey, Preliminary Analysis of the October 1, 1965 Coup in Indonesia, Interim Report Series (Ithaca: Cornell Modern Indonesia Project, 1971).

10 “Dari Buku Putih Sampai Cornell Paper," Tempo, October 6, 1990, p. 29.

11 See Anthonie C. A. Dake, In The Spirit of the Red Banteng; Indonesian Communists between Moscow and Peking, 1959-1965 (The Hague: Mouton, 1973) and The Devious Dalang: Soekarno and the So-Called Untung Putsch: eyewitness report by Bambang S. Widjanarko (The Hague: Interdoc, 1974); and John Hughes, The End of Sukarno: a coup that misfired and a purge that ran wild (London: Angus and Robertson, 1968). 
power in 1966 was to demonstrate, even the enormity of Sukarno's persona could not entirely compensate for the chaos and poverty of the 1960s, nor could it erase the trauma of 1965. The tragic events that followed the coup, including the quiet and lonely end to Sukarno's own life, still weigh on the Indonesian psyche, making reflection about Sukarno a somewhat difficult task.

And yet Sukarno has consistently been a hot topic throughout the New Order; polemics about Sukarno have erupted regularly in the twenty-four years since his death, occurring more and more frequently as time has gone on. Between the years of 1987-1994, for example, Sukarno's picture and/or name appeared on the covers of Tempo and Editor no less than twenty times. Since Tempo and Editor were banned this past June, Sinar magazine has picked up the mantle, carrying Bung Karno's face on its cover three times within the past five months. Indeed the recent commotion in the press can be seen as just the latest skirmish in a long battle to sort out Sukarno's legacy and establish his proper place in Indonesian history. In this sense, Manai Sophiaan's book and the Buku Putih can only make sense in light of Indonesia's protracted struggle to come to terms with Sukarno.

This paper, then, will trace the history of Sukarno's image since his death on June 21, 1970. How, if at all, have perceptions about the first President changed over the course of the past twenty-four years? What role, if any, has the New Order government played in shaping public perception of Sukarno? And towards what ends? With the historical progression of New Order thought about Sukarno as a guide, we can then return to Manai Sophiaan and the Buku Putih. Why did both Manai Sophiaan and the government release such works in 1994? Does the debate which has accompanied these works represent a new phase in Indonesian thinking about their first president or rather the continuation of a long established trend? Why does Sukarno continue to haunt the Indonesian consciousness in a way that no other revolutionary or historical figure has?

\section{Enforced Silence (1970-1978)}

Much has been written about the fall of Sukarno. ${ }^{12}$ I will therefore limit myself here to the major events which contributed to his downfall in hope of establishing the national mood between the botched coup and Sukarno's death in 1970. The failure of the coup attempt in 1965 inexorably changed the delicate balance of forces on which the President had based his regime since the outset of Guided Democracy in July 1959. Sukarno relied heavily on tension between the two major actors in Indonesian politics, ABRI and the PKI, for political stability. By the early 1960s, a triangular constellation with President Sukarno at the top was firmly in place, but the tension between the army and the PKI continued to mount. Though the power triangle fluctuated during the early 1960s, Sukarno continued to remain at its apex, playing ABRI and the PKI off of each other with considerable skill. With the failure of the coup attempt and the subsequent eradication of the Communist Party, the President was forced into a power struggle with the army. With the PKI out of the way and the army determined to assert control, Sukarno found himself and his policies increasingly ignored. Student groups poured into the street by the thousands in early January 1966, demanding a halt to rising prices as well as the dissolution of the PKI, which the army had successfully portrayed as the brutal and sinister force behind G-30-S. As the economy unraveled and Sukarno refused to dissolve the PKI, demonstrations escalated throughout February. The massive demonstrations displayed a high level of organization and

12 See J. D. Legge's Sukarno: A Political Biography (Australia: Allen \& Unwin, 1984), p. 390, footnote 45, for a good discussion of the variety of literature on the coup and Sukarno's loss of power. 
coordination, and there is considerable evidence of army support in the provision of transportation for demonstrators. ${ }^{13}$

As Jakarta plunged into chaos and the nation teetered on the brink of civil war, the army, under General Soeharto's leadership, gave Sukarno an ultimatum: step aside and we'll restore order. And so on March 11, 1966, Sukarno signed an order delegating authority to Soeharto "to take all necessary steps to guarantee security and calm and the stability of the running of the government and the course of the Revolution." 14 This was essentially the end of Sukarno, though his removal from the presidency was to come in several stages. Soeharto, perhaps concerned about his own legitimacy or wary of setting the wrong precedent, was extremely careful to dethrone Sukarno by constitutional measures, though he had acquired more than enough power to simply force the president from office. On June 20, the provisional People's Deliberative Congress (MPRS) confirmed the order of March 11 and revoked its 1963 decision which made Sukarno President for Life. Several months later, the MPRS called on Sukarno to give his own account of G-30-S as well as an explanation of the economic and moral deterioration of the nation. Against a backdrop of student demands that Sukarno be tried and punished for any role he might have played in the coup, the MPRS on February 17, 1967 rejected Sukarno's account of his leadership.

Sukarno's position had fully eroded. Three days later he signed away all administrative powers to Soeharto, clearing the way for the legal transfer of the presidential mandate. On March 27, 1968, the presidency was bestowed upon General Soeharto, formalizing the political realities which had been established two years before. The former president, having seen his policies reversed and national unity destroyed, was confined at first to his home in Bogor, and then to one of his wives' homes in a suburb of Jakarta. After his final exit from the political scene in 1967, cheap Indonesian magazines published lewd stories about Sukarno's sex life, while several newspapers printed disparaging articles about his political performance and his affinity for the Communists. His supporters had been silenced, and everyone else, it seemed, was competing to criticize him. Condemned to isolation, the once worshipped freedom fighter and beloved national leader deteriorated physically and mentally in what were to be his last years. Sukarno died under house arrest on June 21, 1970.

Soeharto had chosen to act very cautiously in regards to Sukarno after the coup, allowing the president to retain many of the outward trappings of power while working quietly and patiently to bring his regime to an end. President Soeharto showed similar delicacy and shrewdness in dealing with the issue of Sukarno's death. Although two of Sukarno's wives, Dewi and Hartini, begged that Sukarno be buried at his home in Bogor, Soeharto refused, apparently unwilling to establish a potential place of pilgrimage or a symbol of dissent for those critical of the New Order so close to Jakarta. Soeharto also refused to have Sukarno buried in the cemetery of revolutionary heroes in Jakarta, choosing instead to lay the first President to rest next to his mother in East Java. While refusing to grant Dewi and Hartini's requests, Soeharto did grant the first president a national funeral. The rushed memorial service paid homage to Bung Karno, with official government spokesmen reflecting on their former leader's merits as well as his mistakes. Sukarno was again acknowledged as the father of his country, but it was a qualified acknowledgment and was not to be the last word.

${ }^{13}$ Legge, Sukarno: A Political Biography, p. 401.

14 Ibid., p. 402. 
In his handling of Sukarno's funeral, President Soeharto established a pattern of behavior towards the first president that was to guide him, albeit awkwardly, through the New Order. His provision of a state funeral for Sukarno accomplished several things simultaneously: it provided a needed outlet for the great, if mixed, emotion felt at Sukarno's loss; it precluded potential charges that Soeharto was disrespectful and ungrateful to his deceased "father"; and it allowed him to portray himself as part of a continuum started by Sukarno. Recognizing the deep wounds that would need to be mended after the massive internal bloodletting which had claimed the lives of anywhere between five hundred thousand and one million people, Soeharto acted to defuse a potentially explosive situation and preserve the fragile new consensus. At the same time, however, he worked behind the scenes to limit the impact of his own move. The speeches made by official government representatives were carefully balanced, the ceremony itself was kept brief, and the gravesite was chosen in hopes of precluding future problems. In short, Soeharto attempted to both co-opt and control Sukarno's legacy. Soeharto would waver between these two tactics for the next twenty-four years of New Order rule.

Immediately after Sukarno's funeral, the government moved to contain his powerful legacy. An embargo was imposed on the republication of Sukarno's political writings, and the first president was rarely, if ever, mentioned by government officials. Despite the fact that the Pancasila, a political philosophy formulated by Sukarno, remained the basis of Indonesian society, references to the first president in relation to the Pancasila were completely omitted. Sukarno, in essence, passed into "purgatorial silence," as his role in Indonesian history was officially ignored. ${ }^{15}$ Against this backdrop, Anthonie C. A. Dake, a political scientist from the Freie Universitaat Bonn, published a controversial book entitled In the Spirit of Red Banteng. This book concluded that Sukarno, not the PKI, was the mastermind of G-30-S. A year later, to strengthen his argument, Dake published The Devious Dalang: Soekarno and the So-Called Untung Putsch; Eyewitness Report by Bambang S. Widjanarko. As mentioned earlier, this book was banned in 1990 after sixteen years in publication. But for the most part, the discussion of Sukarno was limited and controlled during the early 1970s.

After eight years in shadow, Sukarno's image was thrust into the limelight in 1978. In a speech given to the Indonesian Democratic Party (PDI) ${ }^{16}$ on the occasion of the Party's fifth birthday, Lt.-General Ali Moertopo announced Soeharto's plan to construct a funerary complex in Blitar dedicated to the Father of the People, the Proclaimer of Independence, the first President of the Republic of Indonesia, Bung Karno. This announcement marked the end of the silence about Sukarno and the beginning of a controlled revival of his memory.

\section{Reticent Rehabilitation (1978-1980)}

Though the PDI cadres were undoubtedly thrilled by the news, many must have been equally baffled. Why would the government want to honor Sukarno? Several interpretations are plausible. The first, and most obvious, is that the Sukarno card was played as a pre-election ploy. Soeharto, up for reelection later that spring, could have been trying to neutralize discontent amongst lingering Sukarno loyalists, just as he had prevented potential criticism by giving Sukarno a state funeral in 1970. A second and closely related possibility is that Soeharto may have used Sukarno's rehabilitation in an effort to divert attention from the massive student protests of 1977-78 which had been violently

15 Pierre Labrousse, "The Second Life of Bung Karno: Analysis of the Myth (1978-1981)," Indonesia 57 (1993): 175.

16 The PDI was formed in 1973 as a fusion of four parties, including Sukarno's old Nationalist Party of Indonesia (PNI). The fifth anniversary speech by Ali Moertopo was given on January 24, 1978. 
suppressed. Honoring Sukarno on the first windu ${ }^{17}$ of his death had great potential as a public relations stunt designed to woo Javanese constituencies. Soeharto may also have wanted to honor his predecessor for more personal reasons. ${ }^{18}$

Regardless of Soeharto's motives, the decision definitively marked a new era for Sukarno's legacy. The renovation of Sukarno's gravesite was no simple task; 225 graves of revolutionary heroes had to be moved from Sukarno's graveyard to make room for the sprawling mausoleum, while in order to reunite the family, the remains of Bung Karno's father were transported from Jakarta to Blitar, East Java. In June 1979, exactly nine years after Sukarno's death, Soeharto himself officiated at the opening of the complex. The following year, statues of Bung Karno and Bung Hatta were erected on the historical site where they proclaimed Indonesia's independence in Jakarta.

The immediate reaction to Soeharto's decision said much about the state of Indonesian consciousness regarding Sukarno. No less than thirteen books about Sukarno were published within less than a year. A flurry of magazine and newspaper articles were written in honor of the occasion. All sorts of commemorative items-posters, stickers, T-shirts and the like-bearing Sukarno's image sprung up on sidewalks and street corners. The extent and rapidity with which Sukarno's image became common currency apparently caught the government off guard, and Soeharto, concerned by the forces he had unleashed, quickly denounced the commercialization of the affair.

Pierre Labrousse, in his article "The Second Life of Bung Karno: Analysis of the Myth (1978-1981)," discusses the attitudes and ideas expressed about Sukarno through the books and articles published in 1978-1979.

Labrousse has broken down the literature from this period into five thematic categories: Supernatural Powers, The Great Lover, The Tragedy of Sukarno, The New Man, and The Images of Power. The first category, "supernatural powers," deals with the Javanese belief that political power results from the convergence of personal predestination with supernatural powers. Thus in the 1978 books there is an attempt to explain Sukarno's being through divine intervention. Sukarno's discovery of Pancasila is submitted as evidence of Sukarno's privileged relationship with God. The second category, "the great lover," consists of reports describing the country's indulgence of, and admiration for, Sukarno's love of women. Sukarno's women are thought to have contributed to the fertile, masculine "presidential aura" while also contributing to the uniquely national and international character of Sukarno (his wives represented a diverse geographical and cultural base, including East, Central and West Java, Bengkulu, Manado and Japan). The President's wellknown love affair with art is also a subject of considerable importance. Many of the 1978 works speak of Sukarno's presidency as a time in which the arts flourished, in which a uniquely Indonesian artistic tradition was encouraged and supported by the President himself.

A fond remembrance of Sukarno's passion for life, peace, and harmony complements portrayals of Sukarno as the great lover. Anecdotes related to demonstrate the president's preference for nonviolence and his horror of bloodshed reflect an effort to distance Sukarno from the violence of the coup attempt and the terror of the Communist purges. The vision of Sukarno as consensus builder and unifier, and the portrayal of a peaceful and idyllic pre-

\footnotetext{
${ }^{17} \mathrm{~A}$ wind $u$ is an eight-year cycle in Javanese calendrical reckoning.

18 Labrousse, "The Second Life of Bung Karno," p. 175.
} 
1965 Indonesia seem to carry with it a basic rejection of any attempt to implicate Sukarno in the coup. 19

The tragic nature of Sukarno's life is another major theme in the analyzed works. The reader is flooded with references to Sukarno's deprived, impoverished childhood, to the extraordinary obstacles he faced, and to the inordinate suffering which he endured to overcome them. His long history of struggle for the nation is used to place Sukarno in a class by himself. The humiliation and degradation he faced while in exile in Bengkulu and Endeh can only be surpassed by the misery and solitude he was forced to endure in Sukamiskin prison. Many of these works were clearly written to express and elicit sympathy for Sukarno.

This effort to elicit pity for the figure of Bung Karno was most powerfully accomplished by B. M. Diah, who pointed out the tragic irony of Sukarno, the freedom fighter, dying as a prisoner in a free Indonesia. In a collection of articles entitled The Tragedy of Bung Karno, Diah and others recall the ambiguous status granted Sukarno at the time of his death, and they reassert that no proof of Sukarno's collusion in G-30-S was ever established. Sukarno thus died accused but not condemned, and the literature expresses an inner conflict of conscience in coming to terms with the way Sukarno lived out the end of his days. The suffering he was again forced to endure at the end of his life completes the picture of Sukarno as martyr. Sukarno is portrayed as the creator devoured by his creation, as the father neglected by his children in old age, and as an individual cut off from the very forces which gave his life meaning.

The fourth general theme discussed in Labrousse's work is a return to the Old Order concept of the "new man." In these segments, Sukarno in his capacity as engineer and intellectual is put forward as a model of hard work and sacrifice. Sukarno's extensive knowledge of current ideological trends and his desire to assimilate and Indonesianize that knowledge are seen as valuable tools with which to face the future. Though Sukarno's relationship with Islam was hardly free of conflict, this vision of Sukarno as innovator is also discussed in relation to Islam.

The last thematic category identified by Labrousse is that of Sukarno's leadership style. Sukarno's powerful charisma and his privileged relationship with the people are attested to in all of the works of the period. The image of the inspirational orator who brought to life the aspirations of the Indonesian people lives powerfully in the memories of all of these writers. His ideological genius is given substantial coverage, albeit within the confines of authorized doctrines: nationalism, Marhaenism, neutralism, and Pancasila. Sukarno is portrayed as having lived simply and honestly; he never gave government posts to a family member, and he never accumulated personal wealth. His Third World leadership and his legendary rebuke of the United States are seen as sources of great pride for the Indonesian nation. Indeed, thanks to the international attention he brought to the fledgling nation, the figure of Sukarno is seen as confirming the state's very existence.

And so Labrousse's work on the 1978-81 period clearly demonstrates that despite nearly a decade of enforced silence, Bung Karno's image remained alive and well in the memories of many Indonesians. The strength of this image must have taken President Soeharto by surprise. Though he may have rehabilitated Sukarno in an effort to co-opt the current

19 Ibid., p. 184. 
national mood, it is unlikely that Soeharto anticipated unleashing such forces in doing so. ${ }^{20}$ In many ways, the idolization of Sukarno expressed in these works can be taken to imply a critique of his successor. ${ }^{21}$ Sukarno's privileged relationships with the people and with art, his legendary virility, and his oratorical prowess all separate him decisively from Soeharto. Sukarno's charismatic leadership style, idealized as a source of great national pride, is a polar opposite to Soeharto's staid, lackluster persona. The image of Sukarno as a lover of life, peace, and harmony is easily contrasted with that of Soeharto as a ruthless military leader. The attention paid to Sukarno's intellectualism, ideological creativity, and humble financial status can further be seen as a critique of Soeharto's shortcomings. In short, the virtues praised in Sukarno are exactly those missing in Soeharto. The idealization of such qualities, therefore, may well have been a way to express dissatisfaction with the New Order. In hopes of changing the future, these writers found inspiration in the only national past they had.

1978, then, marks a new phase in the expression of sentiment about Sukarno. The tone had changed radically from the days when student protesters were virtually cursing Sukarno in the streets. But no sooner had Sukarno been restored to popularity than a new effort was launched to dethrone the deceased.

\section{The Sukamiskin and Pancasila Controversies (1980-1981) 22}

In an article published in Kompas in September of 1980, journalist Rosihan Anwar dealt Sukarno's image the first blow. Rosihan, formerly a prominent member of the Indonesian Socialist Party (PSI) and editor-in-chief of the party's daily newspaper Pedoman-both of which were banned by Sukarno in 1960-was no fan of the former President. ${ }^{23}$ While ostensibly discussing stylistic differences between Sukarno and Mohammed Hatta (Indonesia's first Prime Minister), Anwar questioned the former's consistency and bravery. He cited a book by John Ingleson on the history of the Indonesian nationalist movement, which contends that while in Sukamiskin prison in 1933, Sukarno had begged for clemency from the Dutch by allegedly writing four letters in which he offered to renounce his political activities in exchange for his freedom. ${ }^{24}$ According to Ingleson, the letters, which are in the archives of the former Minister of Colonies in The Hague, cannot be "dismissed as a temporary aberration" nor discounted as forgeries. ${ }^{25}$ Rosihan Anwar accepted Ingleson's analysis and tried to use the issue of the letters to diminish Sukarno's status as an independence hero.

The reaction to Rosihan's article was swift and decidedly hostile. Throughout the Indonesian press, articles, interviews, and editorials responded to Rosihan's portrayal of the former president with vehemence. Sukarno's wife and companion during the period in

\footnotetext{
20 At least one of the books of this period, Imaginary Interview with Bung Karno, by Christianto, was banned in 1978.

21 Labrousse, "The Second Life of Bung Karno," p. 195.

22 For a more detailed investigation into the controversies of this time period, see Oey Hong Lee, "The Sukarno Controversies of 1980/81," The University of Hull Centre For Southeast Asian Studies, Occasional Paper No. 4 (1982), on which I largely base my account.

23 The PSI was banned in 1960 for its participation in a rebellion in West Sumatra. Rosihan, in fact, is a native of Kubang Nan Dua, West Sumatra.

24 J. Ingleson, Road to Exile: The Indonesian Nationalist Movement 1927-1934 (Singapore: Heinemann Educational Books, 1979).

25 Ingleson, Road to Exile, p. 220.
} 
question, Ibu Inggit, forcefully denied the possibility that Sukarno had attempted to surrender, and journalists immediately began to question the authenticity of the letters. If the letters were authentic, why hadn't the Dutch agreed to the bargain? Why hadn't the Dutch published them in an effort to discredit Sukarno? Why were the documents only declassified once Sukarno was no longer around to disprove their authenticity? Some proposed that the letters were a concoction of the Dutch intelligence service and others demanded to know if Rosihan had seen and read the letters himself. 26

What is interesting for the purpose of this paper is not the question of the historical validity of the letters but the fact that most Indonesians voiced the opinion that they were probably fakes. A fierce debate dragged on for months as supporters of Sukarno rallied to the first president's defense. Many, like respected University of Indonesia (UI) historian Onghokham, insisted that Sukarno's role in the independence struggle could never be diminished, regardless of the so-called Sukamiskin letters. ${ }^{27}$ Finally in a press conference on February 19, 1981, the government moved to put an end to the polemic which had grown increasingly contemptuous of Rosihan and supportive of Sukarno. Adam Malik, then VicePresident of Indonesia, expressed his and President Soeharto's opinion that the actions of Bung Karno had already been written about, and so it was useless to continue questioning the actions of the dead. Though he could hardly have known it at the time, Malik was outlining the position that the government would take repeatedly over the course of the next fourteen years: Sukarno has already passed away; digging up questions about him can only damage national unity and stability; it's best to forget about his past mistakes.

The government's neutral attempt at damage control was only mildly successful. Confronted with the probability that Ingleson's source had been only typed copies of originals no one could find, Rosihan published a response to his critics in which he contended that further debate on the authenticity issue would be fruitless. ${ }^{28}$ Wounded, but unwilling to concede defeat, Rosihan tried again to prove that Sukarno was weak and irresolute in the face of hardship. In a second article published in Kompas, five months after his first article appeared, Rosihan stated that in 1948 President Sukarno pledged to lead the Indonesian people in a guerrilla war against the Dutch. He said that this statement was printed that year in his political journal Siasat, but that the president never abided by his word. He argued that in surrendering to Dutch troops who surrounded Yogyakarta on December 19, 1948, Sukarno broke his promise to the Indonesian people.

Unfortunately for Rosihan Anwar, his second attempt to discredit Sukarno's leadership during the independence struggle also backfired. A charge was led against him in the press, interestingly enough by another former Sukarno opponent, Mohammed Roem. (Roem's party, Masyumi, was banned at the same time as Rosihan's PSI). A week after Rosihan's editorial was printed, Roem, in an article entitled "Perkembangan suatu Polemik" (Development of a Polemic), charged that Rosihan was painfully unfamiliar with history. ${ }^{29}$

\footnotetext{
26 It was subsequently revealed in an editorial by former Masyumi activist, Mohamad Roem, that the letters which exist in The Hague are only typed copies of letters allegedly written by Sukarno. Though the typed copies are authentic in that they were typed by a Dutch official in accordance with regulation, they neverthless do not bear the signature of Sukarno. The whereabouts of the originals, supposedly written longhand by Sukarno, are unknown. See Roem's article "Surat-surat dari Penjara Sukamiskin," Kompas Minggu, January 25, 1981, or Oey Hong Lee's account of his letter in "The Sukarno Controversies of 1980/81," pp. 11-13.

27 Oey Hong Lee, “The Sukarno Controveries of 1980/81,” p. 10.

${ }^{28}$ Rosihan Anwar, "Surat-surat Ir Sukarno kepada 'Procureur Generaal' Hindia Belanda," Kompas, February 14, 1981.

${ }^{29}$ Mohamad Roem, "Perkembangan suatu Polemic," Kompas, February 23, 1981.
} 
Roem explained that surrender to the Dutch was the result of a collective decision by the Indonesian cabinet which was led not by President Sukarno but by Prime Minister Hatta. Roem further insisted that even if Sukarno had spearheaded the movement, the surrender showed great rationality and foresight in preventing many unnecessary deaths at the hands of an overwhelming Dutch force. The polemic developed no further.

Rosihan Anwar was roundly defeated, but Bung Karno was not to rest peacefully for long. Barely six months later another controversy erupted, this time regarding the former president's role in discovering the Pancasila. ${ }^{30}$ The Pancasila, or Five Principles, is the fundamental philosophical basis of the Indonesian state. It had long been acknowledged that the term "Pancasila" and the ideas expressed therein had first been delineated by Sukarno in a speech before the Japanese-sponsored Body for the Investigation of the Preparation of Indonesian Independence (BIPII). The speech, given on June 1, 1945, expressed Sukarno's belief that the Indonesian state should be based on the five principles of nationalism, internationalism (humanitarianism), democracy (consent), social justice, and belief in God. ${ }^{31}$ These five principles, in Sukarno's estimation, would provide the basis for the unity of the Indonesian people in the nationalist struggle and beyond. The Pancasila was later incorporated into the Preamble of the 1945 Constitution, though the order of the principles was shifted to read as follows: belief in God, humanitarianism (internationalism was not mentioned), nationalism, democracy, and social justice. Although the young Indonesian state was to experiment with several subsequent constitutions, Sukarno ultimately returned to the 1945 Constitution with its Pancasilaist Preamble, and this one has remained in effect throughout the New Order.

Not only is the 1945 Constitution still valid, but the Pancasila principle remains a cornerstone of New Order policy. In fact, as one observer has written, "one can say without exaggeration that the present regime in the New Order is obsessed by the Pancasila." 32 The Soeharto Government has gone to extraordinary lengths to spread its interpretation of the five principles. In 1978, the same year that the renovation of Sukarno's grave was announced, President Soeharto started a drive for the comprehension and practice of Pancasila, called Pedoman Penghayatan dan Pengamalan Pancasila, or simply P4. The program, which continues today, consists of intensive refresher courses designed "to enhance the political education of the people...[to] improve the people's awareness of their rights and duties as citizens, which, in turn, would enable them to take an active part in the activities of the state and in national development." 33 Soeharto established on the national level an Advisory Team on the Implementation of P4, a Team for the Preparation of Instructors and Instruction Material for Civil Servants, and an Agency for the Development of Instruction in the Implementation of P4, each with coordinating bodies at the local level. Civil servants and Armed Forces personnel have been required to attend these mass indoctrination sessions while other strata of society have been encouraged to do so.

\footnotetext{
${ }^{30}$ When talking about the Pancasila, Sukarno often said that he did not create the Five Principles out of nothing, but rather that they had always been embedded in the Indonesian consciousness. He only uncovered or discovered them.

31 The speech was published in Indonesian as "Lahirnya Pancasila" as well as in translation as "The Birth of Pancasila," in Jakarta, 1950.

32 Oey Hong Lee, "The Sukarno Controversies of 1980/81," p. 19.

33 Soeharto, Soeharto: My Thoughts, Words and Deeds, as told to G. Dwipayana and Ramadhan K.H. (Jakarta: PT Citra Lamtoro Gung Persada, 1988), p. 288.
} 
Just three years after the P4 campaign began, an article on the Pancasila appeared in Sinar Harapan, written by the Head of the Center for the History of the ABRI, Nugroho Notosusanto. ${ }^{34}$ In this article Nugroho stated that Bung Karno was actually not the first person to put forward the principles expressed in the Pancasila as the basis of the Indonesian state. Bung Karno, according to Nugroho, was just the first person to name these principles "Pancasila." Citing excerpts of speeches from a book by Muhammad Yamin, a fellow participant in the BIPII hearings, Nugroho concluded that the primary creators of the Pancasila were Muhammad Yamin, Supomo, and Bung Karno-in that order. With this as his premise, Nugroho went on to question the designation of June 1, 1945 as the birthday of the Pancasila.

Although this was the first time that this thesis had been presented in the mass media, Nugroho had already formulated these ideas a year earlier in a booklet with the same title. Furthermore, the reevaluations of the Pancasila authored by Nugroho coincided with similar challenges quietly initiated by the government. Soeharto had already abolished the celebration of the birth of Pancasila on June 1 and prohibited commemorative activities on that day. In fact, by the time Nugroho's article was published the MPR had already recognized on three different occasions (1966, 1973 and 1978) that the legal and authentic Pancasila was the one expressed in the Preamble of the 1945 Constitution, which includes neither Sukarno's notion of internationalism nor his original ordering of the principles. More illustrative yet of the government's support for Nugroho's thesis, the sixty-eight-page booklet he produced in 1980 became part of the indoctrination package used in the government-sponsored refresher courses, while the Department of Education and Culture made the booklet obligatory reading for school teachers in a promotion course on Pendidikan Moral Pancasila (Education in the Pancasila Moral). Implicitly then, the Pancasila so crucial to New Order rule is not the same as that elucidated by Sukarno in 1945.35

Like Rosihan Anwar, Nugroho was quickly met by a cavalry of critics. The scholarly nature of his work was immediately questioned, and his methodology and scientific procedure were sharply criticized. Many asked how Nugroho could have based his entire thesis on just Yamin's book, and the book itself became the subject of a fierce debate. Many doubted its reliability and validity as a historical source. ${ }^{36}$ Furthermore, Nugroho was chastised for discounting statements made by Bung Hatta in which he had doubted the authenticity of parts of Yamin's book. ${ }^{37}$ Nugroho was also attacked for ignoring a letter known as "Hatta's Testament," written by Hatta to Guntur Sukarnoputra, first son of the former president. The Testament, which had been published in full over a year earlier,

\footnotetext{
34 Nugroho Notosusanto, "Proses Perumusan Pancasila Dasar Negara," Sinar Harapan, August 3, 1981.

35 Oey Hong Lee, "The Sukarno Controversies of 1980/81," p. 20.

36 Again the issues are clouded by a problem of missing originals. Yamin's book, Naskah Persiapan Undangundang Dasar 1945, consists of transcriptions of speeches made at the BIPII sessions in 1945. In this book, Nugroho finds that two speeches made before Sukarno's, one by Yamin on the 29th of May and one by Supomo on the 31st of May, include a discussion of Pancasila-like concepts. Therefore, Nugroho concludes that Sukarno's June 1st speech was not the first time the Pancasila had been uncovered (he also implies that Sukarno's speech was just a reformulation of other people's ideas-i.e. plagiarism). The original stenographers' transcriptions of the BIPII sessions, however, were borrowed by Yamin in preparation for his book and never returned. Like the original letters allegedly written by Sukarno from Sukamiskin, the whereabouts of these transcriptions remain unknown.

37 Bung Hatta had headed a "Committee of Five" in 1975 to clarify lingering problems about the birth of Pancasila, particularly in relation to Yamin's book. He and the other four members, who had all been actively involved in the original constitutional proceedings, concluded that Yamin's book was dishonest and unsubstantiated.
} 
stated that Sukarno's June 1 speech had been enthusiastically received by all at the BIPII session. It furthermore testified that a subcommittee of nine men (including Hatta, Sukarno and Yamin) had been created to reformulate the Pancasila as introduced by Sukarno. ${ }^{38}$ According to Hatta, though the committee made minor changes, the sole basis of the Pancasila as found in the Preamble of the 1945 Constitution was Sukarno's June 1 speech.

Journalists, scholars and politicians all joined in the outcry against Nugroho. ${ }^{39}$ On Independence Day (August 17), two weeks after Nugroho's article first appeared, the Sukarno-Hatta Institute issued a "Pancasila Declaration" carrying seventeen signatures, which reaffirmed that June 1 was the birthday of the revered principles. Amongst the signatories were such prominent and diverse names as Jusuf Hasyim (leader of the Islamic party, PPP), Usep Ranawijaya (former leader of the Democratic Party, PDI), Dharsono (former Secretary General of ASEAN) and Hugeng (former commander of the national Police Force). The Declaration was read in a solemn ceremony on August 17 in front of the recently built Sukarno-Hatta Monument at Proclamation Street in Jakarta. ${ }^{40}$

Although it is not within the scope of this essay to evaluate the validity of either Rosihan Anwar's or Nugroho Notosusanto's claims, it is nonetheless important to examine their causes and consequences. Though it is tempting to see the two controversies as part of a coordinated governmental plot to sully the image of the former president, there does not appear to be any evidence that the two efforts were linked. They are both, undoubtedly, a reaction against the very visible outpouring of sympathy for Sukarno between 1978-1980. Rosihan Anwar, a political enemy of Sukarno's who still carried a grudge against the former President, seemed to be venting his personal frustration against the glowing images of Sukarno which had suddenly surfaced. Nugroho's case, however, is considerably more complicated; it seems that he set out, with the approval of the government, to adjust the scales of public opinion to a more "balanced" understanding of Bung Karno. It is indeed probable that in 1980 President Soeharto felt that those scales needed immediate calibration. Was he directly behind Nugroho's drive to diminish Sukarno's role? Although Nugroho's article provoked widespread hostility in the press, President Soeharto promoted him shortly thereafter to the post of Rektor (President) of the University of Indonesia in Jakarta. Was he placed there, as has been suggested, to further depoliticize the students who had irritated Soeharto in $1977 ?^{41}$

Indeed the case of Nugroho Notosusanto deserves closer attention and could, in fact, be the subject of a separate inquiry. A native of Rembang who held a doctorate in history from the University of Indonesia in Jakarta, Nugroho was to enjoy a long career marked by his periodic attempts to restrain the power of Sukarno's legacy. In 1968 Nugroho along with Ismail Saleh released The Coup Attempt of the September 30 Movement in Indonesia, apparently in response to the controversial analysis of the coup written by Benedict Anderson and Ruth McVey. ${ }^{42}$ In their work, Nugroho and Ismail developed the interpretation favored by the government: that the force behind the coup had been the PKI, whose ranks Sukarno had allowed to swell in the 1950s and early 1960s. A decade later, Nugroho was the head of a

\footnotetext{
38 “Hatta's Testament," Sinar Harapan, March 17, 1980.

39 Please refer to Oey Hong Lee's "The Sukarno Controversies" for the plethora of articles and statements which criticized Nugroho Notosusanto.

40 Oey Hong Lee, "The Sukarno Controversies of 1980/81," p. 34.

${ }^{41}$ Ibid., p. 35.

42 Anderson, McVey, Preliminary Analysis of the October 1, 1965 Coup in Indonesia.
} 
team which wrote the original White Book on the coup. ${ }^{43}$ The White Book was never released to the public, but its conclusion was similar to that of Nugroho's earlier work. Though neither of these works directly accused Sukarno of collusion, the charge that the PKI expanded exponentially under the first president left open the interpretation that the PKI (and G-30-S) had enjoyed Sukarno's blessing. In 1980-81 Nugroho was working to diminish Sukarno's role in the development of Pancasila, while in 1985 he was busy discrediting the former president in Sejarah Nasional Indonesia (National History of Indonesia). In Volume VI of this series of secondary school textbooks, Nugroho again took issue with Sukarno's position in 1965, describing his protection of the PKI in the face of army objections. He also opened a new front of attack against Sukarno, portraying him as a corrupt leader who accepted commissions from foreign contractors which were subsequently placed in foreign banks. The book, drawing fire from both Sukarno's family and a committee of scholars, was ultimately withdrawn by the government and revised.

This criticism notwithstanding, Nugroho's New Order star continued to rise. From the position of Head of the Center of ABRI's Military History (Kepala Pusat Sejarah Militer ABRI) with a titular rank of Brigadier General, Nugroho was promoted to Rektor of UI in 1982 and then designated Minister of Education and Culture shortly thereafter in 1983. He held both of these influential positions until his death on June 3,1985. The ideas expressed within his works, therefore, cannot be dismissed as personal opinion; they must be taken to reflect at least tacit approval, if not active encouragement, by the Soeharto Government. Soeharto, having unknowingly unleashed the powerful forces of nostalgia for Bung Karno in 1978, may well have turned to Nugroho Notosusanto in an effort to debunk the Sukarno myth.

Nevertheless, both Nugroho's and Rosihan's efforts backfired, as unfavorable responses poured in from both former supporters and detractors of the first president. Sukarno's illustrious image, having just been reinstalled in 1978, apparently could not be shaken; the nationalist reflex to come to Sukarno's defense proved a potent force. Soeharto, perhaps realizing that his government would not be able to ignore Sukarno, much less erase his memory, thus continued to seek the delicate balance in which Sukarno could be respected and even admired, but only within carefully controlled parameters which he himself would define.

Throughout the 1980s, the strength of Sukarno's image was evidenced by the thousand or more people who visited the first president's tomb in remote Blitar each day. Rachmawati Sukarnoputeri, Sukarno's third child and chairman of the Sukarno Education Foundation, tried to open a university in Jakarta bearing her father's name, but was denied government approval in 1984. A year later, however, Soeharto began another drive to co-opt the first president's aura. In July 1985 President Soeharto dedicated Jakarta's new international airport to Sukarno and Muhammad Hatta. In November 1986, Sukarno and Hatta were both posthumously awarded the title of "Independence Proclamation Hero" in a ceremony at Merdeka Palace. Photos appeared in many of the Indonesian dailies showing the Soeharto family graciously welcoming Sukarno's fourth wife, Ibu Hartini, and his five children by his third wife to the ceremony at the Palace. This drive to rehabilitate Sukarno took place against a backdrop of economic austerity measures and painful market liberalization implemented in the wake of the oil crash of the early 1980s. Faced with the need to restructure after a decade of freedom under the oil umbrella, the Father of Development may well have feared that he couldn't rely entirely on his economic track

43 The 1978 White Book was put together by Nugroho Notosusanto, Durmawel Achmad and Sunardi D.M. 
record with elections around the corner in 1987. Manipulation of Sukarno's legacy may well have been an effort to redress that problem.

At the same time, it is interesting to note that in both the dedication of the airport and the ceremony at Merdeka Palace, Sukarno was acknowledged in tandem with Hatta. As at least one observer has noted, perhaps this was Soeharto's new strategy, diffusing the spotlight on Sukarno by recognizing him only alongside Bung Hatta. This way Soeharto could look as though he were making a gracious gesture towards national reconciliation while at the same time acting cautiously so as not to drag up Old Order demons. ${ }^{44}$ The important thing for the Soeharto Government was to diminish Sukarno's utility as a symbol of resistance to the New Order. But as the 1987 elections approached, Soeharto's delicate balancing act was challenged as Bung Karno's image was again thrust to the forefront of political life.

\section{Bung Karno and the PDI (1987)}

The Indonesian Democratic Party (PDI) was formed in 1973 in response to a government restructuring of the party system. In accordance with the 1973 government decree, Protestant (Parkindo) and Catholic Parties, Sukarno's old Nationalist Party (PNI), the Murba Party and the army based League of Supporters of Indonesian Freedom (IPKI) were all herded into the PDI, the four existing Islamic Parties were merged into the United Development Party (PPP), while the government created an electoral organization called Golkar to which all civil servants had to claim loyalty. Since its inception, PDI has been the weakest of the three; in 1977, PDI received only 8.6 percent of the vote, and in 1982 this decreased to a paltry 7.9 percent. After 1982, in fact, the government was worried that the PDI might disappear altogether, but in 1987, much to everyone's surprise, PDI rebounded to win eleven percent of the vote. Although PDI's increase was only three percentage points in absolute terms, it represented a thirty-eight percent improvement over 1982 and resulted in a gain of sixteen seats in Parliament to bring its total to forty.

A number of factors contributed to the PDI's gains in 1987, the most visible of whichthe use of Sukarno's image-was the most disconcerting in government circles. In 1986 the PDI leadership approached Sukarno's children in hopes of recruiting them on behalf of PDI in the upcoming elections. Despite a family pact to remain above all political parties, Megawati Sukarnoputri, Sukarno's second child and oldest daughter, accepted the invitation. Both she and her husband ran for and were elected to Parliament on PDI tickets. Although the PDI Chairman, Suryadi, denied that the party had set out to initiate a rebirth of the cult of Sukarno, PDI leaders must have been hoping that the entrance of the former President's daughter, who bears a striking resemblance to her handsome father, would ignite a spark and give the party a boost. Since the PDI consists largely of old PNI members, Suryadi and others undoubtedly hoped that the romantic story of Sukarno's daughter emerging to lead the remnants of her father's party would set the forces of nostalgia into motion and translate into victory at the polls. But even the PDI leadership must have been surprised by the remarkable response to the figure of Megawati.

Megawati Sukarnoputri was a thirty-nine-year-old housewife with no former political experience when she agreed to run for Parliament in 1987. Although she had never been a national figure, she was met by massive crowds chanting her name wherever she campaigned. Thousands of youth wearing the red T-shirts of PDI and carrying posters and banners with Sukarno's image swarmed to hear Megawati speak. As she spoke to the

44 Shim Jae Hoon, "Hail to the Chief," Far Eastern Economic Review, December 11, 1986: 46. 
adoring crowds, raising and shaking her fist in her father's characteristic style, Mega gave expression to many of her father's ideas and advanced PDI's compassion towards the poor and commitment to social justice. When PDI leaders came for a rally, young supporters flooded into the streets with Sukarno's image draped over their jeeps and trucks. Others, riding motorcycles or jogging alongside, simply carried photos of their new-found hero. Tshirts bearing Sukarno's and Mega's images became big business for sidewalk vendors, as did the posters and buttons that had provoked Soeharto's ire almost a decade earlier in 1978.

Despite PDI insistence that they were not using Mega as a preelection PR stunt, it is clear that Mega proved capable of drawing forth enormous support and emotion. Nearly $10 \%$ of Indonesians were voting for the first time in 1987, and PDI set out to woo these youth. ${ }^{45}$ PDI claimed to be the party of the future and did so, ironically, by recalling the past - a past that most of the young voters who flocked to PDI rallies were too young to remember. So how are we to explain PDI's appeal to this constituency? Soerjadi's capable leadership, mass media support, ABRI's apparent neutrality, and most importantly, PPP's inability to consolidate in the wake of the NU pullout, must all be seen as having contributed to PDI's relative strength in $1987 .{ }^{46}$ But Sukarno's image, coupled with a PDI platform stressing economic equality, anti-nepotism, anti-corruption, and compassion for the wong cilik or little people, clearly struck a chord with Indonesian youth. After twentyone years of New Order economic development and political control under Soeharto's lackluster leadership, Indonesian youth seem to have been longing for the charisma and magnetism of a leader like Sukarno. And Megawati, as the embodiment of her father, seems to have fulfilled that role.

PDI's success must also be seen as a reflection of the dissatisfaction with present conditions; those angered by New Order economic policies which had contributed to an increasingly visible gap between the rich and the poor could take comfort in the figure of Bung Karno, who believed in the dream of an equitable distribution of wealth. PDI's increased strength, then, was probably more a protest against the New Order than an expression of genuine loyalty to PDI. And so despite Soeharto's preventative efforts, Sukarno's image remained a powerful symbol of discontent with current conditions. After the election, Soeharto ordered a study of the modern history textbooks used in Indonesian classrooms to discover why young voters seemed to have so little appreciation of the negative aspects of Sukarno's regime. ${ }^{47}$

Following the April elections, Sukarno seemed to be at the height of his New Order rehabilitation. But he was not to rest quietly atop his pedestal for long; within a year, a new debate blew up in the press following the publication of a controversial new book.

45 "Survey of Political Developments," RIMA [Review of Indonesian and Malaysian Affairs], Summer 1987: 143172.

46 In 1984, Nahdatul Ulama (NU)-an Islamic organization closely linked with the Javanese traditionwithdrew its support from PPP. In 1987, NU figures traveled the country saying that "a vote for PPP is not required, for Golkar not prohibited, for PDI not a crime." As a result, many of NU's ranks crossed over to PDI or Golkar. See R. William Liddle's "Indonesia in 1987: The New Order at the Height of Its Power," Asian Survey, February 1988: 180-191.

${ }^{47}$ R. William Liddle, "Indonesia in 1987," pp. 186-7. 


\section{The Specter of Communism}

In May, 1988, retired Colonel and former army intelligence officer, Soegiarso Soerojo, released his book, Siapa Menabur Angin Akan Menuai Badai: G-30-S dan Peran Bung Karno (meaning something to the effect of "Who[ever] Sows the Wind will Reap the Hurricane: G30-S and The Role of Sukarno"), causing a colossal commotion. The 578-page book is broken down into five chapters: Struggle for Independence, Era of Liberal Democracy, Guided Democracy, Era of the New Order, and Conclusion. In Siapa Menabur Angin, Soegiarso talks about the history of the PKI, about Marxist and Communist strategies, and about the two times that the PKI rebelled prior to the 1965 coup, but the focus of his attention is on the political domination of the PKI in the 1960s. He discusses at length the extent of Bung Karno's support for the PKI and insists that such support was carried out systematically from the 1950s. He argues that instead of destroying the PKI after the Madiun Affair in 1948, Sukarno allowed the organization to rebuild and grow stronger. He also discusses the birth of Supersemar and the start of the New Order under General Soeharto. ${ }^{48}$

None of this, of course, was new; much of the literature over the past twenty years had discussed such issues. So why the brouhaha? Soegiarso, as a former army intelligence officer, had access to many sources which had never before been released to the Indonesian public. The evidence he presented consisted of excerpts from documents seized from PKI members, confessions obtained through military interrogation, sources from the government's intelligence agency Bakin, as well as reports and findings from sessions of Mahmillub (Mahkamah Militer Luar Biasa), the military court which tried those involved in G30-S. Soegiarso's book is supplemented with 178 pages of documents relating to G-30-S, including texts of speeches, court decisions, testimonies and decrees. He used all of this information, plus a good deal of personal opinion, to establish Sukarno's role in the tragic events of 1965.

In his twenty-five page conclusion, Soegiarso contends that Sukarno was a Marxist, that he was ideologically in harmony with the Communists, and that as such he must have acquiesced to, if not colluded in, G-30-S. His probe goes so far as to suggest that Sukarno was the dalang ${ }^{49}$ or mastermind of the plot, though his accusations come largely in the form of rhetorical questions and insinuations: "Benarkah Bung Karno tidak tahu-menahu tentang rencana pembantaian yang akan dilancarkan PKI hari itu ... Benarkah Bung Karno sama sekali tidak terlibat dalam peristiwa G-30-S?" (Is it really true that Sukarno knew nothing about the plans of the slaughter which were to be launched by PKI that day? Is it really true that Sukarno was not at all involved in G-30-S?) 50

It was this combination of charges, that Sukarno was a Marxist, a Communist, and behind the coup attempt in 1965, that touched on sensitivities and ignited a fury in the second half of 1988. Magazines and newspapers were flooded with editorials about Soegiarso's book, bringing the Sukarno polemic to a new height. The press was filled with articles reexamining Bung Karno and the Old Order, trying to make sense of Sukarno's confused ideological legacy and to assess Soegiarso's charges of his being a Marxist and a Communist. There were long sections in magazines like Tempo and Editor devoted to a

48 "Supersemar" is an Indonesian acronym meaning Surat Perintah Sebelas Maret or the "order/decree of the 11th of March." This letter in 1966 effectively transferred power from Sukarno to Suharto and is commonly recognized as the start of the New Order.

49 A dalang is the narrator and puppeteer of traditional shadow plays, but is frequently used, as it is above, to mean the mastermind of a plot or event.

50 Soegiarso Soerojo, Siapa Menabur Angin Akan Menuai Badai (Jakarta, 1988), p. 392. 
reexamination of G-30-S and to a review of the literature about Bung Karno and the coup.51 A kind of soul-searching about the Old Order ensued, and though no definitive answers were given in relation to the many riddles Sukarno left behind, two trends were clearly discernible: extraordinary hostility to Soegiarso's work and a resounding rejection of claims that Sukarno was a Communist.

Following the release of his book, Soegiarso Soerojo was quoted as saying, "It's already time that our national history be straightened out, written objectively so that it can be a reflection for our leaders in the future as well as for the young generation who do not yet know their real national history." 52 Soegiarso, it would seem, was as shocked as President Soeharto to see the outpouring of affection for Sukarno from youth the year before. Soegiarso said that Bung Hatta's statements about Bung Karno as released in a book called Bung Hatta Menjawab (Brother Hatta Answers) were the original inspiration for his book. In Bung Hatta Menjawab, Hatta addressed many questions about the PKI, from revolutionary times up to the party's destruction in 1966. In speaking of G-30-S, Hatta was quoted as saying, "I presumed that this incident was at least known about by Bung Karno, moreover it was very possible that he himself was behind it. This was a reaction and association of thoughts which were strengthened by my own feelings. Without the consent of Sukarno, I felt that this thing could not have happened." 53

After reading Bung Hatta's words, Soegiarso decided to write a book of his own. ${ }^{54}$ Using Hatta's words as his point of departure, Soegiarso resolved to prove Sukarno's complicity in G-30-S. In an interview with Editor in September 1988, Soegiarso said that in his investigative reporting he used logic only 5 percent and feeling 95 percent of the time. 55 But this technique was highly criticized, as people charged that Soegiarso invented, fabricated, and concocted stories. Like Nugroho Notosusanto before him, Soegiarso's methodology was bitterly challenged, and his book was attacked by historians and journalists alike as amateurish, poorly researched, and irresponsible.

Indeed discrepancies in historical fact helped stoke the political fire. In Soegiarso's book, the Bupati of Nganjuk, for example, is included in a list of East Java's local leaders who had become lackeys of the Communists in $1963 .{ }^{56}$ But the man who had held that position in 1963, unlike the other Bupati's on Soegiarso's list, was still alive in 1988 to defend his position. Ironically, Soendoro, the Bupati of Nganjuk during the period in question, was considered anti-Communist and was often the focus of PKI attacks. Petitions were frequently posted and circulated by the PKI calling Soendoro "Satan of the city" and a lackey of neo-colonialist forces. While the other Bupatis listed are said to have "disappeared" after the coup (i.e. were purged and/or murdered), Soendoro enjoyed a long political career, continuing as Bupati until 1968, serving in the DPR until 1971, then acting as an advisor to the Governor of East Java until 1978. Soendoro first found out that he had been mentioned in Soegiarso's book while reading the newspaper.

51 See Tempo issues on September 17, September 24 and October 1, 1988; Editor issues on September 24 and October 1, 1988 and April 8, 1989.

52 "Menabur Angin, Menuai Badai," Tempo, September 17, 1988.

53 Mohammad Hatta, Bung Hatta Answers (Singapore: Gunung Agung, 1981), p. 49.

54 "Mengingatkan PKI Lewat Bung Karno," Editor, April 8, 1989, p. 12.

55 "Investigasi Perasaan," in Editor September 24, 1988, p. 11.

56 Soegiarso Soerojo, Siapa Menabur Angin, p. 181. 
Soendoro filed a 1.5 milyar rupiah (roughly half a million dollar) lawsuit against Soegiarso Soerojo, saying that his name had been ruined. "You can't imagine how hurt a person is who is accused of being PKI. It's not only me who has felt it. But my wife, my children, and my relatives have also been affected." 57 It was reported in Editor that as a result of his implication in Siapa Menabur Angin, Soendoro's family had suffered material loss and social burden; some clients canceled their contracts (Soendoro is a lawyer), and neighbors gave the family the cold shoulder. Soendoro publicly announced his intention to settle the matter in a court of law and promised to produce high profile witnesses, including retired General Soemitro, to prove that he had never been pro-PKI. Soegiarso ultimately backed down and retracted his statement about the Bupati of Nganjuk.

While Soegiarso did not explicitly name Soendoro in his book ${ }^{58}$, others weren't so lucky. The Rektor of Universitas 17 Augustus, Sadjarwo, was named in Siapa Menabur Angin as the former leader of Barisan Tani Indonesia (BTI), a peasant union which was ultimately taken over by the PKI. As a result of this reference, the press made an issue of the Rektor's prior PKI ties. What Soegiarso had forgotten to explain, however, was that when Sadjarwo was involved in BTI, the organization was not yet affiliated with the PKI; in 1956, when it became clear that BTI was oriented towards the PKI, Sadjarwo apparently had left the organization. On the insistence of the seventy-year-old Sadjarwo, Soegiarso clarified the issue in the third edition of his book.

In a similar case, Murdio Djungkang was named as the founder of Barisan Sukarno (Sukarno Front) in Central Java. ${ }^{59}$ Barisan Sukarno was an organization of Sukarno supporters established to balance the student movements (KAMI/KAPPI) which were united against Sukarno and the PKI. Murdio Djungkang had been arrested in March 1966 due to suspected PKI involvement, but was released three years later due to a lack of evidence. The sixty-one-year-old Murdio remembers what it was like to be a suspected Communist and did not want to experience such accusations again. "I am worried that people will think that I was PKI," Murdio explained, "and that could really damage and pollute my good name." 60 He contested Soegiarso's contention that he was the founder of Barisan Sukarno and announced his intention to sue the writer for libel.

The statements made by both Soendoro and Murdio Djungkung expressing fear and abhorrence at being labeled PKI are poignant reminders of the deep scars left by the catastrophic events following the 1965 coup. When the army blamed the coup on the PKI, it also set into motion a propoganda attack through which PKI cadres were vilified and dehumanized. According to the army, the Generals who were victims of the coup had been brutally beaten and mutilated by members of Pemuda Rakyat (the PKI youth movement) and Gerwani (the PKI women's movement). Before being thrown into what was known as Lubang Buaya (the Crocodile Hole), the Generals were said to have suffered from eyegouging and castration at the hands of merciless PKI members, though the official medical team's reports provide no evidence of such mutilation. ${ }^{61}$ The army also launched a campaign to persuade anti-Communist notables and political leaders that thousands of

57 "Soendoro: Siapakah Dia?" Editor, April 8, 1989, p. 16.

58 Only the position of the Bupati of Nganjuk in 1963 was mentioned.

${ }^{59}$ Soegiarso Soerojo, Siapa Menabur Angin, p. 534.

60 "Serba-Serbi Yang Fatal," Editor, April 8, 1989, p. 17.

61 See Benedict Anderson's, "How Did the Generals Die?" Indonesia 43 (April 1987): 109. 
holes similar to the Crocodile Hole had been prepared by the PKI for their burial in the event of a Communist takeover. ${ }^{62}$

The -message from the army was clear: it's us or them. And the evidence suggests that the Indonesian people were able to convince themselves this threat was real. Though much of the killing was related to the settling of old scores, the legitimizing and justifying principle behind the massacres was that Communists are evil. Once the populace had been convinced of the threat, the purging of Communist elements from society was viewed not just as a necessary evil, but as a duty and a right. Thirty years later, Communist demons still lurk deep in the Indonesian subconscious. Encouraged by periodic government warnings to be wary of the ever-present Communist threat, people continue to associate Communism with evil incarnate. For people like Soendoro, Murdio Djungkung, and Sadjarwo, being an accused Communist in 1988 was still anathema, as it had been in 1965, so that even the hint of it could ruin their reputations and careers. Despite the PKI's annihilation in 1966 and the massive international decline of Communism in the decades that followed, the PKI issue has remained a major one throughout the New Order. Only within this framework can the scale of the uproar caused by Siapa Menabur Angin be understood.

Given this context, it would seem that Soegiarso's effort was doomed from the start; in calling the first president of Indonesia a Communist, Soegiarso exceeded the acceptable boundaries of discourse. Any value his book may have had was entirely overshadowed by the nationalist reflex to deny that Sukarno could have been a Communist. People who might otherwise have been more receptive to Soegiarso's antipathy for Sukarno came to Sukarno's defense without hesitation. Former KAPPI protesters, ABRI officers, and politicians all proclaimed their confidence that Sukarno was not PKI. "We all know Bung Karno was not Communist," said Admiral Sudomo, then Coordinating Minister for Security and Political Affairs (Menkopolkam). ${ }^{63}$ Retired General Soemitro also said with conviction that Bung Karno was not PKI. ${ }^{64}$ Gani Djemat, judge for the Mahmillub (special military tribunals) which tried those involved in the coup, affirmed that during the sessions not a single witness ever said that Bung Karno was a Communist or the dalang of G-30-S. He added that as PKI was then a large legal party, Bung Karno as President was obliged to listen to them. ${ }^{65}$ Former KAPPI demonstrator Eki Syachruddin took issue with Soegiarso's premise that Sukarno had been polluted by his "unclean environment" - i.e. early contact with Communist leaders like Muso, Alimin and Semaun from his days as a schoolboy at Tjokroaminoto's home, as well as subsequent ties with Aidit and Nyoto-saying that such logic would ultimately condemn many of Indonesia's national heroes. ${ }^{66}$

Of course, Sukarno's more traditional supporters, including his family, were also vocal in the crusade against Siapa Menabur Angin. Dewi Sukarno, amongst many others, accused Soegiarso Soerojo of trying to make money off of Bung Karno's name. Rachmawati Sukarnoputeri said that if Soegiarso's book were followed through to its logical conclusion,

62 Pipit Rochijat, “Am I PKI or Non-PKI?” Indonesia 40 (October 1985): 44.

63 “Rekaman Berbagai Sudut Pandang," Editor, September 24, 1988, p. 16.

64 “Mengingatkan PKI Lewat Bung Karno," Editor, April 8, 1989, p. 11.

65 Ibid., p. 15-6.

66 "Menabur Angin, Menuai Badai," Tempo, September 17, 1988. In 1916 a fifteen-year-old Sukarno moved from his parent's home in Mojokerto to Surabaya. While attending highschool in Surabaya, Sukarno boarded with Sarekat Islam leader Tjokroaminoto. It was there, at Tjokro's house, that Sukarno came into contact with a whole host of first-generation nationalists, including Semaun, Musso and Alimin. See J.D. Legge, Sukarno: A Political Biography, pp. 54-55. 
Indonesia's revolutionary history would have to be rewritten because everything would smell of Communism. In a stinging letter to Kompas, Rachmawati's first son, Rommy Hendra Rahtomo, wrote, "Mama says, Bung Karno was a great hero. He made our country independent and the government has honored him as Independence Proclamation Hero." So if Soegiarso's accusations are true, Rommy asked, doesn't that mean that our country was founded by a Communist? ${ }^{67}$

The polemic had crossed the boundary into the unthinkable. As the debate grew heated, the government and the army finally emerged in a united front. In a clear effort to defuse both criticism of Soegiarso and praise of Sukarno, Minister of the Interior Rudini developed the theme that had been introduced by Adam Malik eight years earlier during the Rosihan Anwar debacle: mikul dhuwur mendhem jero. ${ }^{68}$ According to President Soeharto, "mikul dhuwur means to respect our parents and uphold their good name. Mendhem jero means that we should not call attention to shortcomings...[but] should bury deeply what we see as their mistakes so that these shortcomings cannot be discerned." 69 In choosing this very Javanese response to the crisis, the government was able to appear magnanimous in its desire to respect Sukarno while avoiding taking a direct stand on the issues involved. But this attitude of praising the good and burying the bad carried with it the implication that there was bad to be buried, an insinuation which undoubtedly did not escape a society all too familiar with New Order innuendo.

Thus the government left Soegiarso's accusations open while shifting the focus of the discussion to the overriding issue of familial obligation. Rudini was quoted as saying that the problem was not one of myths about Sukarno, but whether or not there was a child cursing (memaki) his father. ${ }^{70}$ What was at stake, the government seemed to be saying, was not Communists and coups but manners and protocol. It was Indonesia's collective responsibility to accentuate the good and forget about the bad, to treat their father with the respect that all fathers deserve. This ideology of burying past mistakes in the form of mikul dhuwur mendhem jero has remained the Soeharto government's quintessential response to Sukarno up to the present day.

While Rudini was busy preaching mikul dhuwur mendhem jero to the press, the army joined the campaign to quiet the gathering storm. In a speech to students at Universitas Diponogoro in Semarang, Chief of the Social and Political Affairs Staff (Kepala Sosial Politik) Lt.-General Harsudiono Hartas, called for an immediate end to the polemic, denouncing the vilification of Indonesia's deceased father. ${ }^{71}$ Endorsing mikul dhuwur mendhem jero and calling Soegiarso's book unimportant, General Harsudiono stated that the government commitment to Bung Karno as symbolized in the Independence Proclamation Hero title and in the name of Jakarta's airport would be adhered to firmly. Saying that "We are now building our nation, so there's no point in wasting our energy," the General asked both the attorney general and the Minister of Information to examine Soegiarso's book and put an end to the debate. ${ }^{72}$

67 “Spekulasi Di Lapangan Licin," Editor, September 24, 1988, p. 8.

68 Soeharto supposedly first said this to Sukarno in a meeting at Istana Merdeka in March 1966 before the handing down of Supersemar.

${ }^{69}$ Soeharto, My Thoughts, Words and Deeds, p. 141.

70 "Topan di Atas Bung Karno," Tempo, October 1, 1988, p. 36.

71 Ibid.

72 "Topan di Atas Bung Karno," Tempo, October 1, 1988, p. 37. It is interesting to note here that while General Harsudiono was calling for an end to the Sukarno polemic, Minister of the State Secretariat Moerdiono 
Rudini's and Harsudiono's pleas to bury the past were virtually a verbatim recitation of the position President Soeharto took in his autobiography. The autobiography, entitled Soeharto: Pikiran, Ucapan, dan Tindakan Saya (Soeharto: My Thoughts, Words, and Deeds), had just been released to the public several weeks before Siapa Menabur Angin. Knowing the sensitivity to the Sukarno issue, Soeharto dedicated a whole chapter to the edification of the mikul dhuwur mendhem jero principle in relation to Bung Karno, saying that the most important advice he'd ever received in his life was to respect one's elders. ${ }^{73}$ In other sections of the book, Soeharto made it clear that in his opinion, Sukarno had been a victim of both the PKI and his own ambition. ${ }^{74}$ Though he mentioned Sukarno's reluctance to punish those involved in the coup, Soeharto said that this had been in an effort to save not the Communists, but his policies. Soeharto duly noted that in the course of the special military tribunals there was no evidence that Sukarno had been involved in the coup. Calling him an "extraordinary patriot" and a "freedom fighter," Soeharto said that Sukarno was a hero worthy of tribute.

Implicitly, then, Soegiarso's accusations had already been refuted by the president himself, a detail which was largely overlooked by the press. But the problem then arose, if Sukarno was not a Communist, what was he? Professor Sartono Kartodiroljo acknowledged that Sukarno frequently read Marxist books, but insisted that this didn't mean that he was a Communist or even a Marxist. Rather, Sukarno was open to all ideologies, according to Sartono, "able to receive everything, including communism" and make it his own. Others wrote that Marxism was just an intellectual exercise for Sukarno -- a tool of analysis, a tactic with which to fight colonialism and imperialism. Bung Karno was neither Marxist nor Communist, but nationalist, many wrote, citing his founding of the PNI, his Islamic spirit, his complete belief in God, and his great love of Indonesia as proof. ${ }^{75}$

As this struggle to understand Sukarno and his ideological legacy continued, labeling Sukarno proved an elusive task. Many expressed the opinion that Sukarno himself hadn't reached an ideological conclusion; his fundamental principles were nationalism and unity, but he had tried to achieve his goals by integrating the positive points of many ideologies. Sukarno himself had frequently acknowledged this; in a 1941 article entitled "Sukarno by Sukarno Himself," Sukarno wrote, "What is Sukarno? A nationalist? An Islamist? A Marxist? Readers, Sukarno is a mixture of all of these 'isms'." $76 \mathrm{He}$ later was quoted as saying, "I have made myself a meeting point of all trends and ideologies. I have blended, blended, and blended them until finally they became the present Sukarno." 77 This proved

announced that anyone has the right to write a history book and that the decree of the MPRS in 1967 (rejecting Sukarno's account of his leadership) had already proven that Sukarno had made mistakes. Ultimately, neither the book nor the polemic were banned. After checking the book, the Attorney General proclaimed that it was not a threat to national stability and public order. In a statement which sounded entirely out of step with the current national mood, he said that Soegiarso's book only discussed historical facts and that those facts had already been proven to be correct ("Jangan Ditutup-tutupi," Editor, October 1, 1988). In a similar statement seemingly out of tune with the times, retired General Sarwo Edhie stated that Soegiarso's book was objective and that its conclusions were correct. He said that Bung Karno was not brought to justice only so that the Republic of Indonesia could continue to respect him as a hero. (Personal opinion or a government subplot?)

73 Soeharto, My Thoughts, Words and Deeds, p. 141.

74 Soeharto, My Thoughts, Words and Deeds, pp. 209-210.

75 "Rekaman Berbagai Sudut Pandang," Editor, September 24, 1988, p. 14.

76 Legge, Sukarno: A Biography, p. 341.

77 lbid. 
problematic for a society which has been systematically taught to label political ideology as well as race and religion.

In a particularly eloquent commentary on the difficulty of defining Sukarno, Goenawan Mohammad wrote that Sukarno continues to be like a "gelora" (passion or tempestuousness). A gelora intimidates and spellbinds but can not be precisely defined. It is like a nebulous cluster which is far away in the sky; it could be a cluster of stars giving off light, or it could just be a layer of mist/fog which is luminous. "Sukarno was indeed not Communist or Leninist. He was not the champion of a specific ideology-if with ideology we mean a body of ideas which can act as a guide to answer all questions and at the same time be a reference for action. 'Sukarnoism,' in the end, truly evades expert analysts. The nebula still exists far away in the sky. Only giving off light. Only intimidating. And the further away it gets, the more it intimidates." 78

After weeks of heavy criticism, Soegiarso confessed that his book should not be considered a history book but a journalistic work, an investigative report. He also admitted not having cross-checked the authenticity of his sources. In the final paragraph of Siapa Menabur Angin, Soegiarso wrote "let it be that [Bung Karno and Bung Hatta] are valued as the proclaimers of independence, but we don't need to make cults of them."79 Clearly concerned by the idolization of Sukarno in the 1987 elections, Soegiarso had set out to redress the balance and halt Sukarno's deification. But with every effort to push aside the myth, the myth has grown stronger. In a survey conducted in twelve Indonesian cities by Tempo magazine in the midst of the uproar, 72 percent of the 918 respondents said that Bung Karno was not Communist while only 3 percent said he was (the rest being unsure or leaving the question it blank); forty-four percent said that Sukarno did not support G-30-S, while only 7 percent said he did; 59 percent said that Bung Karno was not the dalang behind G-30-S while only 2 percent said he was; and finally 85 percent of those who answered Tempo's questionnaires said that Sukarno's merits outweighed his mistakes while only 1.2 percent felt the opposite. ${ }^{80}$

Even more dramatic proof of Bung Karno's increased stature was released in Editor on the same day. To gauge student perceptions of Bung Karno after the Soegiarso Soerojo affair, a student newspaper at Diponogoro University administered a survey similar to one it had administered the previous year following the 1987 elections. ${ }^{81}$ The results were as follows:

\footnotetext{
78 "Bung Karno," Tempo, September 24, 1988.

79 Soegiarso Soerojo, Siapa Merabur Angin, p. 396. Note that Soegiarso uses the government technique of discussing Sukarno alongside Hatta. It is fairly safe to say that few people have made cults of Bung Hatta in the New Order, and so it would seem that Soegiarso included Hatta in this category to make his efforts seem more neutral towards Sukarno.

80 This survey is particularly interesting in that seventy-one percent of the respondents were between the ages of seventeen to thirty-five, and thus most were either children or had not yet been born in Sukarno's day. See "Bung Karno dan Anda dan Jasa dan Kesalahannya," in Tempo, October 8, 1988.

81 “Bung Karno Indikasi Apa?" Editor, October 8, 1988, p. 22.
} 


\begin{tabular}{llcc}
\hline & & May 1987 & October 1988 \\
\hline $\begin{array}{l}\text { Is Bung Karno the number one } \\
\text { national figure whom you }\end{array}$ & Yes & $52.5 \%$ & $72.381 \%$ \\
admire? & No & $39.167 \%$ & $22.857 \%$ \\
& Unsure & $8.23 \%$ & $04.762 \%$ \\
\hline & & & \\
Is a figure like Bung Karno & Yes & $56.67 \%$ & $77.143 \%$ \\
needed nowadays? & No & $23.33 \%$ & $15.238 \%$ \\
& Unsure & $15.83 \%$ & $07.619 \%$ \\
\hline & & & \\
Do we need to awaken & Yes & $57.50 \%$ & $74.286 \%$ \\
admiration for Bung Karno? & No & 34.167 & $22.857 \%$ \\
& Sometimes & $8.33 \%$ & $02.857 \%$ \\
\hline
\end{tabular}

Though methodology is certainly a concern, even with a substantial margin of error the trends in both surveys are striking. Soegiarso Soerojo, like Rosihan Anwar and Nugroho Notosusanto before him, seems to have fed the very fires he endeavored to extinguish.

Two years later, an unsuspecting Lee Kuan Yew of Singapore was to inadvertently prove just how strong Sukarno's symbol had become. In his Singapore National Day rally on August 26, 1990, Lee Kuan Yew compared Sukarno to Soeharto, saying that Sukarno had focused on external issues like those of Malaysia and Dutch New Guinea because he couldn't handle his nation's internal problems. Following the publication in Indonesia of these seemingly harmless remarks, letters flooded in to the press and to the Singaporean Embassy. A range of senior figures in Jakarta criticized Lee in uncharacteristically strong terms. Suryadi, the mastermind behind the 1987 PDI success, was quoted in Kompas as saying "If Singapore wants to continue its friendship with Indonesia, it should strive to better understand the culture of the Indonesian people." 82 Statements such as Lee Kuan Yew's were considered "unbecoming from a neighbor and could not be accepted by Indonesians." 83 An article in Kompas regretted Lee Kuan Yew's "less than accurate evaluation of Bung Karno's role," while Merdeka blasted the Prime Minister of Singapore for not respecting Indonesia's national heroes. Merdeka also reminded Lee Kuan Yew that it was as commander in the West Irian campaign that President Soeharto had risen to prominence. ${ }^{84}$

Lee Kuan Yew must have been genuinely surprised by the severity of the statements coming out of Jakarta. Unaware of the current thinking about Sukarno, the Prime Minister of Singapore touched on sensitivities that were more about domestic politics than foreign relations. As if being confronted by an imperialist attack, Indonesians reacted defensively to protect their national treasure. Bung Karno, indeed, was alive and well in the New Order.

\section{Bung Karno, Mega and the PDI}

In the elections of 1992, the PDI leadership clearly hoped to capitalize on the momentum and thus further the gains they had made in the previous elections. Only this time, the government had learned its lesson; photos or posters bearing a person's image were banned

82 "A Study in Contrasts," Far Eastern Economic Review, September 13, 1990: 10.

83 "Indonesia: MP's Criticize Lee Kuan Yew's Comments on Sukarno," Business Times (Singapore), August 31, 1990 , p. 7.

84 “A Study in Contrasts," Far Eastern Economic Review, September 13, 1990: 10. 
from political rallies and campaigns nationwide. Despite the new restriction, PDI was still able to play the Bung Karno card in the form of his children. Megawati's younger brother, Guruh Sukarnoputra, and her brother-in-law, Taufik Kemas, both joined her in PDI's election drive. Mega and Guruh both charmed enormous crowds and were able to seize the attention and the affection of many young people. The PDI made substantial gains, demonstrating growth outside of its traditional stronghold in Java and gaining sixteen seats overall. Golkar, however, fell from a New Order high of 72 percent in 1988 to 67 percent of the vote in 1992. In some areas, Golkar's decline was even more pronounced; in Central and East Java, for example, Golkar suffered a 12 percent decrease. ${ }^{85}$

It is difficult to say to what extent Sukarno's legacy played a role in the 1992 elections. While many have since claimed that the government ban on Sukarno's image in the 1992 campaign allowed PDI to prove that it didn't need Bung Karno for success, it must be acknowledged that while his photo wasn't there, his image was readily found in the faces of his children. Given the presence of Mega and Guruh, the extent of the party's association with Sukarno in 1987, and the historical relationship of its PNI component to the first President, it would not be difficult to see the PDI as still linked to Sukarno.

At the same time, PDI's growth in areas where Sukarno was never particularly popular, such as North Sumatra, Riau, South Sumatra, West Nusa Tenggara, Central Nusa Tenggara, and East Timor, indicates that other factors were also involved. In 1992, nearly 60 percent of PDI voters came from the young generation, i.e. they were first or second time voters. What continues to attract the masses and the young people is not Bung Karno per se, but what he has come to symbolize: opposition to the New Order. PDI, as an opposition party which stresses social issues (at least in electoral campaigns), has become the logical choice for youth who are dissatisfied with the status quo and thus feel no compunction to vote for Golkar. Many among the young generation who know little about the politics of the 1960s but feel constricted in the age of development with its calculations and functional proposals, are longing for a romantic and poetic kind of leader. For others, the PDI is simply the only way to register protest with the current situation. ${ }^{86}$ What better way to express discontent with Soeharto than to flaunt admiration of the man he dislodged?

Any lingering questions about the role pro-Sukarno sentiment played in the 1992 elections were largely answered a year later when PDI chose its new party chairman. In July 1993, the PDI held a conference in Medan to elect the next party chairman. Soerjadi, the chairman who had so successfully orchestrated PDI's successes in 1987 and in 1992, was easily reelected to the position. But the government, both concerned about Soerjadi's previous success and angry with his charges of government corruption and calls for presidential term limits during the 1992 campaign, made every effort to topple him. Ultimately, the government refused to recognize Soerjadi's reelection and the Congress disintegrated into a bloody, chaotic mess. The Medan Congress was adjourned without the selection of the PDI chairman.

Ostensibly to prevent further chaos, the government appointed a twenty-three-man caretaker board to run PDI's next Congress, which was scheduled to take place in Surabaya the following December. The government, in rejecting Soerjadi, was to come face to face with a far greater problem. Following the Medan debacle, the Jakarta branch of the PDI

85 "PDI: Bukalah Mata, Telinga dan Hatimu," Tempo, December 4, 1993.

86 The one exception to this is the "Golput" phenomenon. In the 1992 elections, a sizable number of disgruntled youth declared themselves part of the Golongan Putih (White Group) and registered their dissatisfaction with the state of Indonesian democracy by refusing to vote for any of the political parties. 
nominated Megawati for the position of chairman. In a rare display of internal unity, PDI branches from all over the country quickly followed suit. Support for Megawati poured in from all over, including from such diverse personalities as Adnan Buyung Nasution (who had helped topple Sukarno) and Sri Bintang Pamungkas (a political opponent from PPP). The government, ostensibly fearing a revival of "Sukarnoism," however, supported its own candidate. ${ }^{87} \mathrm{By}$ the opening of the Surabaya Conference, there were only two candidates: the popularly supported Megawati and the government/ABRI choice, Budi Hardjono.

In the weeks prior to the Congress, the hottest topic of conversation was whether or not Soeharto, the government, and/or ABRI would accept Megawati's nomination. The common perception was that the Soeharto government would never allow one of Sukarno's children to head a political party. Despite assurances by ABRI Commander Feisal Tanjung and Minister of the Interior Yogie S. Memet that the government would not interfere, it was widely reported that Mega's nomination was being obstructed. In what was later called the "Solo incident," the Solo branch of PDI rescinded its support of Megawati just days before the December Congress. It was widely acknowledged that the Solo PDI backed down due to government pressure. The Southern Sulawesi branch subsequently announced that they would boycott the Surabaya Congress if they continued to be pressured by the government to revoke support for Megawati. ${ }^{88}$ Many delegates were coerced in their home provinces into signing declarations that they would not support Megawati, though most ultimately defied these statements once they arrived in Surabaya.

These were just a few signs that the government and the army were not as neutral as they claimed. But few could have anticipated what was to ensue in Surabaya. Due to the overwhelming support for Megawati, the government-appointed caretaker board was forced into a prolonged filibuster to prevent Mega from being elected. The board first tried to arrange for the chairman to be elected by an electoral committee, a process which would have favored the government-backed candidate. When this motion failed, the caretaker board and pro-Budi constituencies simply absented themselves from the final day of the congress, thereby ensuring that a final vote for the chairman, as well as the secretary-general and the new central executive board, could not be taken. At midnight on December 6, the government's strategy became clear; police moved in and dispersed the PDI delegates claiming (and rightly so) that their license to hold the congress had expired. ${ }^{89}$ The Surabaya Conference was thus a repeat of its predecessor; despite the fact that 256 out of 303 delegates had ignored official pressure and thrown their support behind Megawati, the congress ended without the selection of a new chairman.

Meanwhile, outside the building in which the congress was taking place, throngs of Megawati supporters had set up camp. Dressed in PDI red or wearing T-shirts with Mega's photo, the crowds proclaimed their loyalty to Sukarno's first daughter. Lyrics to the old song "Bung Karno, siapa yang punya... yang punya kita semua" (Brother Karno, who does he belong to...he belongs to all of us) were changed to include Megawati and were sunghysterically at times-at every possible opportunity. Megawati-mania was not limited to Surabaya; as the drama unfolded at the PDI Congress, even becak (pedicab) drivers in

87 The issue of a rebirth of "Sukarnoism" again led to an intense review of Sukarno's ideology in the press. Marxism, Marhaenism, and Sukarnoism were all discussed at length in an effort to understand what it was that the government was afraid of. Because this discussion is a virtual repeat of that which took place in 1988, I have not discussed it here again.

88 "Menghadang Mega dengan Sukarnoisme," Forum Keadilan, December 9, 1993, p. 91.

${ }^{89}$ A license is required to hold a gathering of more than six people in Indonesia. 
Central Java were not immune to the fervor. I can remember one becak driver in Yogyakarta at the time of the congress. As he approached me on his becak, I saw his tattered, yellow Golkar shirt; as he pedaled away, I saw large capital letters spelling "M-E-G-A" in black magic marker on the back. Megawati Sukarnoputri had become not just a national figure, but a star.

How can we account for the massive support that Megawati received prior to and during the Surabaya conference? "We love Bung Karno and his children, so we support Megawati," said one PDI delegate from Bali. ${ }^{90}$ Other delegates similarly admitted that they nominated Megawati because she has the charisma of her father. ${ }^{91}$ And so, as in 1987 and 1992, Mega's relationship to Bung Karno played a direct role in her prominence. Despite Mega's glaring lack of political experience, her supporters clearly believed that with the charisma she inherited from her father she could unite the fractious PDI. They hoped that like her father, Megawati would become a champion of the peasantry and defend their needs in a changing world. ${ }^{92}$ Her backers may have thought that like Benazir Bhutto in Pakistan, Aung San Suu Kyi in Burma, and Cory Aquino in the Philippines, Megawati would be able to capitalize on her famous name and lead the opposition to a position of new strength.

But this explanation does not wholly explain the extraordinary events in the second half of 1993. For while young followers may have placed enormous faith in Megawati, it is unlikely that her colleagues shared such optimism. Since being elected to the DPR in 1987, Mega had done little to further the causes of which she spoke so fervently in her election campaigns. In fact, she had hardly ever opened her mouth in DPR sessions. She was, as most members tend to be, a benchwarmer in the Parliament-that is, when she bothered to show up at all. ${ }^{93}$ Though charismatic, Megawati Sukarnoputri is no Benazir Bhutto. So why, then, the massive support among delegates?

It would seem that Megawati's endorsement was largely a measure of defiance to the budaya restu (culture of approval) which has been a major component of political life in the New Order. The fact that all political activity at the national and local levels was tightly controlled by the government had long been a rahasia umum (public secret). Everyone understood that the government screened all poll candidates and was active in saying who could and could not become the head of a party; Soerjadi had not been the first victim of this policy. And so the blatant government interference in the Medan conference served as a painful reminder of the state of Indonesian political development. After twenty-seven years of New Order politics, not a single political party or organization was independent of the government. Paternalism continued to be the dominant political culture. Government approval could launch an unknown into the national spotlight, while disapproval could knock a national figure into oblivion.

\footnotetext{
90 "Bung Karno, Siapa Punya," Tempo, December 18, 1993, p. 21.

91 "Ya, Latief, ya Latief...Mengapa Begini," Forum Keadilan, December 23, 1993, p. 9.

92 Approaching the Surabaya Congress, Megawati published a brochure entitled "Bendera Sudah Saya Kibarkan" [I have already put out the flag] in which she discussed her point of view on various issues, particularly the life of the peasant. Her ideas were clearly heavily influenced by her father's Marhaenist philosophy. In relation to Megawati's nomination for PDI Chairman, Dr. Arief Budiman said that Bung Karno's thoughts about "the little people" were still very relevant and for this reason a rebuilding of Sukarnoismstruggling to defend the poor people-was a positive thing. (See "Menghadang Mega dengan Sukarnoisme").

93 "Tak Usah Khawatir Pada Sukarnoisme," Forum Keadilan, December 9, 1993, pp. 30-34.
} 
In response to the overwhelming frustration felt after the failure of the Medan conference, Megawati's nomination emerged as the perfect vehicle for rejecting such shameless governmental meddling. Megawati was the consummate candidate for the PDI Chair because the government would definitely not want her there. Mega's nomination, therefore, was more a challenge to this "culture of approval" than a ringing endorsement of her personal capabilities. Choosing Megawati meant choosing to place the party above all other considerations, a way of rebuking Golkar and the status quo at the same time. Megawati's presence as the head of the PDI, one observer wrote, "will bring music to the ears of protest voters. PDI is frequently chosen as a rebuke to the government, to Golkar, and to the status quo by people who are tired of governmental restrictions, of the monopoly problem, of the disparate rate of development, of the lack of social justice. Megawati, in her status as Bung Karno's daughter, in her own writings in which she borrowed from her father's ideas, and in that the government doesn't approve of her, is a symbol of all this."94

In the wake of the Surabaya failure, support for Megawati remained strong. Mega declared herself the de facto head of PDI, though her official status was, at best, ambiguous. As PDI stood in a state of limbo, the government made an interesting move. The week after the failed Congress, the heads of Golkar, Harmoko (also Minister of Information) and Siti Hardiyanti Rukmana (Soeharto's daughter), made a pilgrimage to Bung Karno's grave. Accompanied by other top Golkar leaders and thousands of Golkar supporters, Mbak Tutut (as Siti Hardiyanti Rukmana likes to be called) and Bung Harmoko (as Harmoko likes to be called) $)^{95}$ made their way to Blitar. As a sea of yellow T-shirt wearing Golkar supporters stood carrying yellow Golkar banners and Indonesian flags, Harmoko, his wife, and Mbak Tutut knelt, prayed, and scattered flowers at Sukarno's grave. After a ten minute ritual, Mbak Tutut and Harmoko spoke to the press. "I have made a pilgrimage here before, in 1988. As father of the nation," Mbak Tutut said, "Bung Karno belongs to the whole nation of Indonesia. $\mathrm{He}$ is also my father." 96

Similar statements came from Harmoko, as he described to the press his three previous pilgrimages to Blitar. Harmoko and other Golkar leaders present insisted that their affair was not a political pilgrimage, but a personal one. According to Harmoko, there was a convention of Golkar leadership in East Java, and so while in the area, they decided to stop in at Blitar. But few appear to have bought this explanation; Blitar is a remote place and was purposely chosen by Soeharto as such. Harmoko and Mbak Tutut would not have gone so far out of their way for no reason. And if it wasn't a political pilgrimage, why did everyone come dressed in yellow, waving Golkar banners?

This was clearly a political ploy designed to place Bung Karno in a neutral position visa-vis the political parties, to break the exclusive hold on Sukarno's image that the PDI had enjoyed. The message of Mbak Tutut's and Bung Harmoko's visit to Blitar was that Bung Karno belonged to the whole nation, including Golkar. The government was back to its old co-optive tricks. But did the public believe the government's message? An article in Tempo would indicate that it did not. After a long article questioning Golkar's political pilgrimage to Blitar, Tempo journalists wrote that Bung Karno's children clearly had the most right to

94 "PDI: Bukalah Mata, Telinga, dan Hatimu," in Tempo, December 4, 1993.

95 As noted earlier, the word Bung (brother) as a term of address fell into disfavor in the New Order. The acceptble way of addressing a man became the more formal Bapak (father). Harmoko's resuscitation of the term Bung must be seen as an attempt to bring an air of Old Order familiarity to his persona and thus capitalize on the Sukarno momentum.

96 "Bung Karno Siapa Punya," Tempo, December 18, 1993, p. 21. 
use their father's name. The article further stated that, regardless of this right, they had never tried to abuse the privilege of that name, politically or otherwise. In what must be seen as a criticism of the extravagance of Soeharto's children, Tempo went on to explain how all of Sukarno's children lived simply, like most people of Indonesia. ${ }^{97}$

While Golkar was busy reconnecting with Bung Karno, Megawati was touching base with important government officials. In some well publicized visits to government ministers and Golkar leaders, Megawati gave her assurance that they need not fear "Sukarnoism" or "Marhaenism" and gave a commitment to implement a political mandate for PDI that was based on Pancasila. Afraid that Mega could become an uncontrollable political phenomenon, but aware of the intense frustration provoked by the government's interference in Indonesia's democratic conventions, the government and ABRI probably agreed that it was best not to obstruct Mega's appointment any further. Blocking her directly would have validated her status as a threat to the government and made a martyr of her in the process. In the end, Mega got a green light. Three weeks after the collapse of the Surabaya Congress, a special Jakarta convention of regional delegates officially endorsed Megawati and thwarted the caretakers' last ditch effort to place pro-government delegates on her twenty-nine-person executive board.

The drama of Megawati's accession to the top position in PDI was partly a testimony to the strength of Sukarno's legacy and the hope that Megawati, as the beneficiary of that legacy, could lead PDI into the future with the fire and charisma of the past. But it also showed that it has been increasingly difficult for Soeharto's government to impose its will on political structures while employing the rhetoric of openness. Unfortunately for PDI (and for Indonesia), hopes in Megawati may be misplaced; but regardless of her leadership potential, Mega's inauguration as Party Chair was a victory for PDI and a defeat, however small, for the established order.

\section{The Straightening Out of History}

And so it would seem that with Megawati Sukarnoputri occupying the top job in PDI and Golkar leaders making pilgrimages to Blitar, Sukarno's image had reached a New Order high. Despite (and perhaps because of) periodic attempts to discredit him and diminish his historical role, the aura around Sukarno had grown and expanded. In January 1994, Sukarno sat firmly installed atop his New Order pedestal. How, then, are we to explain the intense controversy which followed the publication of Manai Sophiaan's proSukarno book, Kehormatan Bagi Yang Berhak (Respect for Him Who Deserves It), just eight months later?

As mentioned in the introduction to this paper, Manai's book endeavors to clarify Bung Karno's position in the events leading up to, during, and after the tragedy of G-30-S. But his conclusion, that Sukarno was not involved in the coup attempt, had already been argued extensively and successfully following the Siapa Menabur Angin fiasco. So why did the eighty-year-old Manai Sophiaan feel compelled to write this book in 1994? And what caused the strong response to his work?

Manai Sophiaan first met Sukarno during the Japanese occupation, when he was asked to start a newspaper in his hometown of Makassar, Celebes (today Sulawesi). After independence, Manai helped Sukarno found the PNI and served as Secretary-General of the party from 1946 to 1964 . He was then chosen as a member of Parliament from 1950-1964.

97 “Mereka Ahli Waris Nama Besar," Tempo, December 18, 1993, p. 25. 
From 1963-1967, Manai was the Ambassador to Moscow, after which he returned to journalism as editor of the newspaper Suluh Marhaen (1968-1972). Since 1972, Manai has been a columnist for the daily newspapers Merdeka and the Indonesian Observer, as well as the magazine Topik.

Manai Sophiaan's book was released on September 5 to coincide with the author's eightieth birthday. When asked why Manai chose to reopen the issue of Sukarno's involvement in the coup, Manai responded that "respect has to be given to those who deserve it. What's past has passed, yes, but if history has become like this then it needs to be clarified." 98 In his opinion, some people still consider Bung Karno a criminal. "They let Bung Karno die at his house/prison and have portrayed him unfairly as pro-Communist." 99 This, according to Manai, is what needed to be reviewed. He may well have been responding to Soegiarso Soerojo; in a strikingly similar statement to that made by Soegiarso six years earlier, Manai said, "I am only speaking the historical truth . . . I only want to straighten out history." 100 With Megawati in control of the PDI and Golkar publicly paying homage to Sukarno, Manai may have felt that 1994 was the perfect time to fully restore the image of his mentor. "The government's attitude of mikul dhuwur mendhem jero has only gone half way," Manai complained. ${ }^{101}$ Sukarno, according to Manai, has not been placed in a position befitting his accomplishments and his stature.

Manai tried to establish Sukarno's innocence through Sukarno's own words. In a speech known as Nawaksara given to the provisional People's Deliberative Assembly (MPRS), Sukarno had outlined his interpretation of the coup attempt and given an account of his leadership. But the Assembly wasn't entirely satisfied with this explanation and had asked that Sukarno supplement his speech. In a written report submitted to the MPRS on January 10, 1967, entitled Pelengkap Nawaksara (Supplement to Nawaksara), Bung Karno contended that three things had caused G-30-S: the poor, misguided leadership of the PKI; the shrewdness of neocolonialist forces; and the influence of persons who lacked integrity (oknum-oknum yang tidak benar). Although this explanation was ultimately rejected by the MPRS, Manai Sophiaan reexamines Sukarno's Nawaksara defense in an effort to prove that he had been right all along.

Though he discusses such issues as Bung Karno's relationship with the PKI and PKI leader D.N. Aidit's obsession with revolution, Manai Sophiaan focuses mostly on the "neocolonialist factor" in his 330-page book. He traces the history of U.S. interventionist policies in Indonesia through the 1950 s by examining CIA correspondences and reviewing Western literature. He discusses the several assassination attempts made on Sukarno's life, regional rebellions in Sumatra (led by PRRI) and Sulawesi (led by Permesta) which were funded heavily by the US/CIA in 1957-8, as well as the shooting down of American pilot Allan Lawrence Pope. All this is used to establish the tense Cold War framework in which G-30-S took place. He quotes heavily from Geoffrey Robinson's "Some Arguments Concerning U.S. Complicity in the Indonesian 'Coup' of October 1, 1965" which notes that the coup was directly beneficial to U.S. interests; Indonesia came back to the fold, rejoined the UN, halted its campaign against Malaysia, left the Eastern Block (though still claiming neutrality), and welcomed Western capital with open arms. Manai Sophiaan also states

\footnotetext{
98 "Bung Karno Tidak Terlibat!" Tiara, September 25, 1994, p. 32.

99 "Manai Proud of Controversial Book on Sukarno," The Jakarta Post, September 30, 1994.

100 "Saya Hanya Meluruskan Sejarah," Forum Keadilan, October 27, 1994, p. 32.

101 Ibid.
} 
Robinson's assertion that the CIA worked in cooperation with several Indonesian army officers.

In an effort to bolster the importance of the "neocolonialist factor," he supplements Robinson's conclusions with a statement from retired CIA agent Ralph McGehee, in which he commented that the overthrow of Bung Karno had been so successful that it was used as a blueprint for other operations in other parts of the world. ${ }^{102}$ Manai also expresses the belief that U.S. Ambassador Marshall Green, who had purportedly played a role in the overthrow of Prime Minister Mohammed Mossadegh of Iran and President Syngman Rhee of Korea, had been sent by the US to coordinate a plot against President Sukarno. ${ }^{103} \mathrm{He}$ writes that not only the West, but also the KGB was involved in Indonesia, that the situation had grown tense, and that in the midst of this intrigue came G-30-S.

Very little of the information that Manai presented was new. In fact, as I've noted earlier, magazines like Tempo and Editor had summarized the different Western interpretations of the coup on many occasions, including those that directly contradicted the official version of events. However, never before had such a detailed account of the CIA role been published in Indonesia by a prominent Indonesian. In looking at the coup from a Cold War perspective, Manai opened the door to new questions regarding the roles of all of those who had been involved in the coup, including, implicitly, President Soeharto. Knowing the lengths to which the army and President Soeharto had gone to blame the coup on the PKI, and knowing that without this belief the massacres of late 1965 would lose their justification, Manai Sophiaan's book must have caused quite a stir in government circles. Indeed, when PPP leader Ismail Hasan Metareum S.H. called for the banning of Manai's book, saying that "Manai Sophiaan's book could shake the existence of the New Order," he wasn't entirely off base. ${ }^{104}$ But in an interesting twist of fate, it was an interview that Manai gave about the publication of his book, and not the book itself, that generated the fierce polemic that burst into the press at the end of September.

In a now notorious interview with Tiara magazine, Manai Sophiaan discussed his life, his book, and his feelings about the New Order. He spoke at length about America's covert operations in Indonesia, citing various telegrams which he had obtained from foreign diplomats and the American Embassy. But in what was apparently an off-the-record comment to Tiara journalists, Manai said that the student demonstrators, who flooded the streets of Jakarta in 1965-6 calling for the dissolution of the PKI, were unknowingly funded by the United States. He said that the yellow jackets which were worn by thousands of protesters were actually imported from Hawaii and distributed amongst the students. ${ }^{105}$ These statements were to be the first point of contention.

In the same interview, Manai took issue with the politics of the New Order. After pointing out that Sukarno had never stolen from the country and that his children had not become big businessmen, Manai said,

Now, everyday we read about progress, development; but the big houses are not owned by the people, but by conglomerates and foreigners. Nowadays the people are burdened with all kinds of taxes which we never had before. All of the people's land is being taken

\footnotetext{
102 Manai Sophiaan, Kehormatan Bagi Yang Berhak (Jakarta: Yayasan Mencerdaskan Kehidupan Bangsa, 1994), p. 50.

103 Ibid., p. 174.

104 "Buya: Tulisan Manai Sophiaan Bisa Goyahkan Eksistensi Orba," Suara Merdeka, October 4, 1994.

105 “Bung Karno Tidak Terlibat!," Tiara, September 25, 1994, p. 30.
} 
to be made into golf courses. I don't think that this was the goal of our independence, but the Parliament is powerless to do anything ... What is the difference between the Old Order and the New Order anyway? Conglomerates, cooperation with foreign nations, those are the differences. As for the system, its exactly the same . . .only those on top have benefited. 106

Immediately after publication of the Tiara interview, two organizations of former student activists (Fosko 66 and Ikatan Keluarga Besar Laskar Ampera Arief Rachman) held press conferences denouncing Manai Sophiaan. Both organizations admitted that they hadn't read Manai's book, but decried Manai's statements about the student demonstrators having been funded by the CIA. ${ }^{107}$ They took issue with Manai's accusation that their yellow jackets had been imported from Hawaii and claimed, in what seemed to be a ploy to involve the government, that Manai's remarks about the New Order being the same as the Old Order discounted the New Order's accomplishments and distorted the reality of life under Sukarno. They announced their intention to sue Manai in a court of law in order to force the writer to prove his allegations.

The reporters at the press conferences seemed to side with Manai Sophiaan, calling the lawsuit a publicity stunt and asking why they didn't just open a dialogue with the eightyyear-old journalist. ${ }^{108}$ Nevertheless, within days several senior Golkar politicians and government ministers joined the call for legal action. In a statement to reporters, Golkar leader and former student activist Abdul Gafur said that Manai had twisted the facts and that food supplies had come from the "Indonesian people who were still committed to the Pancasila ideology and the 1945 Constitution."109 State Minister of Public Housing Akbar Tandjung said that the demonstrations had been spontaneous and purely motivated by the wish to defend Pancasila from Communism. Calling the students' reputations tarnished, he too called for a lawsuit against Manai. ${ }^{110}$

Manai Sophiaan insisted that he had no intention of offending the students; he had said in his interview that the majority of the students weren't even aware of the CIA involvement. Calling the Tiara journalists unfair, Manai also said that he should prosecute the magazine for printing statements which should have been off the record. ${ }^{111}$ He pointed out that his book discusses neither the issue of the students' involvement nor that of the yellow jackets. Ultimately, Manai retracted what were perceived as his insulting statements in Tiara, but maintained his willingness to go to court if the former activists were still unsatisfied.

In the midst of this drama, another bombshell hit the press. The cover of the October 3 issue of Sinar magazine quoted writer/author Mochtar Lubis as saying, "Bung Karno was definitely involved in G-30-S!" Needless to say, the shock value was high. Not even Soegiarso Soerojo had come right out and said that Sukarno had been involved in G-30-S; he had only insinuated and raised suspicions. But now a prominent figure in the literary

\footnotetext{
106 Ibid., pp. 32-3.

107 The polemic exchanged between Manai Sophiaan and the two organizations of former student activists was reported almost daily for several weeks in most major Indonesian newspapers, starting on September 27, 1994. The Jakarta Post also carried the story starting October 1, 1994.

108 "Pressure Mounts to Sue Senior Columnist Manai," The Jakarta Post, October 3, 1994.

109 Ibid.

110 "Minister Joins Campaign to Sue Columnist Manai," The Jakarta Post, October 8, 1994, p. 1.

111 "Manai: Saya Siap Beri Penjelasan," Suara Merdeka, September 30, 1994.
} 
community had directly accused the first president of involvement in the coup. In an interview with Sinar on the occasion of Manai Sophiaan's book, Mochtar Lubis said that Sukarno's Nasakom ideology, which spoke of the need to unite nationalist, religious, and Communist forces, was stupid and proof of his involvement. He said it was Sukarno who had made the PKI powerful and that this was a sin against the Republic of Indonesia and a betrayal of the 1945 Constitution. Insisting that Sukarno must have known about the coup, he said that the military should have arrested him and thrown him in jail with the rest of the G-30-S conspirators.

Although Mochtar Lubis's distaste for Sukarno had been well documented, never before had such strong statements been published about the first president. The gaps in Mochtar's logic as to how Sukarno was involved in the coup led to an equally strong response. Director of the Institute for Legal Aid and the National Presidium of WALHI (a prominent environmental protection organization) in North Sumatra, Alamsyah Hamdani, said that "Mochtar Lubis sounds like an old man not getting enough attention . . . his statements reflect his narrow-mindedness about the law and indicate that he approves of being jailed without proper legal procedure." He recommended that Mochtar study law from his colleagues at the Legal Aid Foundation. ${ }^{112}$

Others, like respected professor Arief Budiman, wondered what Mochtar Lubis meant with the word "involved." Did Sukarno help plan G-30-S? Or was Mochtar talking about something else? The general opinion seems to have been that Mochtar could say that Sukarno was involved in the PKI if he wanted to-there is plenty of historical evidence to show that Bung Karno and the PKI enjoyed a close relationship-but that he couldn't claim that Sukarno was involved in the murders of the generals. ${ }^{113}$ Mochtar Lubis, who had been jailed by Sukarno, was largely dismissed as an angry old man with a grudge.

Not everyone took Mochtar Lubis's remarks so well in stride. An organization which calls itself Pendukung Proklamator Kemerdekaan Republik Indonesia (Supporters of the Proclaimer of Independence of the Republic of Indonesia) sent a letter to the Supreme Court insisting that the government prohibit the defamation of Bung Karno's good name. Saying that Mochtar Lubis had acted in an "un-Pancasilaist" way by insulting the first president of Indonesia, the organization requested that action be taken against him. ${ }^{114}$ Sukmawati Sukarnoputri, Sukarno's fourth child, also filed a complaint on behalf of her family, claiming that Mochtar Lubis had polluted not only Sukarno's name, but also that of his extended family.

Prompted by the flurry of bad press he was receiving, Mochtar, in the tradition of Soegiarso Soerojo and Manai Sophiaan, declared his "readiness to straighten out history." In a Kompas article on October 20,1994, the writer was quoted as saying that he was ready to face Sukmawati's charges in court. As threats of lawsuits flew wildly about the press, the government released its long-awaited Buku Putih (White Book) entitled Pembrontakan Partai Komunis Indonesia-Latar Belakang, Aksi dan Penumpasannya (The Rebellion of the Communist Party of Indonesia-It's Background, Action and Annihilation). For many years it had been rumored that a White Book was about to be published, but in 1994 Minister of the State Secretariat Morediono had announced that the Buku Putih would finally be

112 "Pemerintah Memberi Standar Ganda," Merdeka, Minggu Kedua [second Sunday] October 1994, p. 11.

113 See, for example, "Dalam Bentuk Apa Terlibat?" and "Bicarakan Bung Karno Harus Bersifat Ilmiah" in Merdeka, Minggu Kedua, October 1994.

114 "Perlu Ada Ketetapan Tentang Proklamator," Merdeka, October 29, 1994. 
published later that year. The book was symbolically released on October 1 to coincide with the twenty-ninth anniversary of the containment of the coup. ${ }^{115}$

But the Buku Putih, as its name suggests, is about the PKI and not Sukarno; in the introduction to the book, Moerdiono wrote that the White Book had been compiled to supply the Indonesian nation with information about the pattern of planned threat from the concepts and actions of Communists in Indonesia. And so despite widespread expectations, the Buku Putih did not answer the question on everyone's mind-was Bung Karno involved in the coup or not? The book is divided into ten chapters, the first five of which are dedicated to putting the Communist coup into historical perspective. The growth and development of the PKI in the twentieth century are discussed in detail in an effort to describe a consistent pattern of ambition to wrest power from the government. The PKI's lust for power, according to the Buku Putih, culminated in the 1965 coup. The sixth chapter deals with the army's suppression of the coup, and the seventh chapter is devoted to Sukarno's role.

In this chapter, actions taken by the President which were perceived as protective of the Communist Party in the period following the coup are discussed at length. Sukarno's attitude and actions are said to be consistent with those recommended by D. N. Aidit in a letter written after the Communist leader fled Jakarta. That is, Sukarno only took action against those members of the PKI who were directly involved in G-30-S, while resisting attempts to dissolve the Party. Moreover, his reluctance to act against coup conspirators Air Vice-Marshall Omar Dhani and Brigadier-General Soepardjo, his creation of a new cabinet in early 1966 with many PKI supporters, and his dissolution of the anti-PKI student group KAMI are all cited as evidence of Sukarno's pro-PKI stance. The analysis of Sukarno's role also includes excerpts of speeches after the coup which highlight Sukarno's inclination to defend Communism. Ultimately, as the White Book explains, the MPRS rejected Sukarno's account of his leadership.

The Buku Putih neither accuses nor absolves Sukarno, leaving the question of his role entirely out of the concluding chapter. Moerdiono said that Sukarno's actions were given a separate section so as to explain the decision taken by the MPRS revoking Sukarno's authority, but that the authors didn't want to make conclusions about whether or not the President had been guilty of wrong-doing. Calling the issue a sensitive and important one, Moerdiono said that their job was not to pass judgment but to present the facts and thus allow each reader to decide for himself. ${ }^{116}$ The eighth chapter deals with the PKI's annihilation, the ninth chapter gives conclusions about G-30-S, and the final chapter, in typical New Order fashion, warns Indonesians to continue to be wary of the latent Communist threat.

The reaction to the Buku Putih was mixed; though many journalists praised the government's foresight and wisdom in allowing the reader to draw his own conclusions about Sukarno's involvement, others expressed disappointment that the government did not take a clearer stand about Sukarno one way or the other. Sukmawati Sukarnoputri, having a busy month defending her father's name, spoke out against the White Book, saying that the coup was orchestrated by the CIA who disliked Sukarno's soft stance on communism. She challenged the government to fill in the gaps and explain why Sukarno

115 Gerakan 30 September: Pemberontakan Partai Komunis: Latar Balakang, Aksi dan Penumpasannya (Jakarta: Sekretariat Negara Republik Indonesia, 1994).

116 “Saya Tidak Berani Menghukum Bung Karno," Forum Keadilan, October 27, 1994, p. 21. 
didn't act against the PKI in the wake of the coup. ${ }^{117}$ Many political observers, including $\mathrm{M}$. Amien Rais and respected historian Onghokham, doubted the government's historical objectivity and questioned its motives in publishing the White Book. ${ }^{118}$

Two months after the books were released, the polemic died down. So where did the chips fall? Has public perception changed in any substantial way? While the trigger issue in 1988 had been the insinuation that Sukarno was a Communist, the debate this time focused on both Sukarno's and the CIA's involvement in G-30-S. As for the latter, most commentators, while acknowledging the student activists' pure motivations, agreed that CIA involvement could not entirely be discounted. One former 1966 activist noted that tons of yellow jackets appeared during the protests, even though beforehand it had been difficult to find the textiles for the University of Indonesia jackets. He also questioned how the consumption needs of the student protesters had so effectively and consistently been met "by the people" when the level of prosperity of Indonesian society was not high enough to support such an enormous movement. ${ }^{119}$ Only government and ABRI representatives, such as retired general and former Minister of the Interior, Amirmachmud, and retired lieutenant general and former Minister of Religious Affairs, Alamsyah, came out to declare that the CIA was definitely not involved in G-30-S or its aftermath. ${ }^{120}$ For the most part, however, observers claimed that there was still not enough proof to say either way.

As for Sukarno himself, his reputation seems to have survived another round. Though Vice-President Try Sutrisno emerged to carry the government's mikul dhuwur mendhem jero torch, calling for an end to the reopening of past mistakes, ${ }^{121}$ people continued to voice their opinions. Pundits, politicians and even the student activists who were suing Manai Sophiaan overwhelmingly agreed that Sukarno was not involved in the coup, ${ }^{122}$ though the logic that brought them to this conclusion was, in many cases, different. Many asked why a president would organize a coup against himself, noting that Sukarno would have been stripped of his power had the coup succeeded. ${ }^{123}$ Others explained that until there is definitive proof, Sukarno must be considered innocent. ${ }^{124}$ In fact, a large proportion of those who added to the debate relied heavily on this presumption of innocence, stating that Sukarno could only be considered guilty had he been brought to trial and convicted. Since this never happened, allegations against him could never be proven and statements of his guilt would not be juridical. ${ }^{125}$

If most everyone agreed that Sukarno was not "involved," the lingering question for those taking part in the polemic was how to explain Sukarno's post-coup attitude towards

117 "Sukarno's Daughter Hurt by White Paper," The Jakarta Post, October 6, 1994, p. 2.

118 M. Amien Rais, “Buku Putih,” Rebuplika, October 10, 1994; “Buku Putih Bukan Karya Sejarah” Sinar, June 20, 1994.

119 "Bung Karno Tidak Tahu Makar G-30-S/PKI," Merdeka, Minggu Kedua, October 1994, p. 1.

120 "Amirmachmud Tentang Sukrno," Kompas, October 1, 1994, p. 13.

121 "Wapres Try Sutrisno: Kesalahan Bung Karno Telah Kita Pendam," Republika, October 8, 1994, p. 1.

122 In all the newspapers that I searched, the only people that came out and accused Sukarno of being involved in the coup were Mochtar Lubis in the Sinar article noted above and Amirmachmud in Kompas, October 1, 1994.

123 One of the statements that the coup conspirators broadcast during their short-lived control over Radio Republic Indonesia included an announcement of a Revolutionary Council that was to run the country. Implicitly the Presidency and the Parliament were to be destroyed.

124 "Belum Ada Bukti Keterlibatan Itu," Sinar, October 3, 1994, p. 21.

125 See "Pemerintah Memberi Standar Ganda," and "Aneh, Baru Dipersoalkan Sekarang," in Merdeka, Minggu Kedua, October 1994. 
the PKI. Three general responses emerged in answer to this question. The first response asserted that Sukarno actually wanted to dissolve the PKI, but that he was either preempted by the army or stripped of power before being able to do so. ${ }^{126}$ The second explanation was that in defending the PKI, Sukarno was being consistent with the Nasakom ideology he had spent much of his life developing. The corollary to this interpretation was that he was also trying to preserve the delicate balance of power between the Communist Party and the army. Without that balance, this group of observers argued, Sukarno knew he would be forced into a showdown with the army. ${ }^{127}$ The third analysis, put forward by Manai Sophiaan, held that Sukarno resisted punishing the PKI because he believed in principle that the coup had been the result of competition between the PKI and a "specific political force" (i.e. the army). ${ }^{128}$

Sukarno's ideology is again discussed at length in 1994, with Mochtar Lubis on one end of the spectrum saying that Nasakom was a stupid idea, and Amien Rais on the other end reminding us that historical figures and their ideologies can only be judged fairly within the context of their time. ${ }^{129}$ Many discussed the continued relevance of Sukarno's ideology; while consensus had it that Nasakom was out of date (ketinggalan zaman), Sukarno's antiimperialist foreign policy and his thoughts about New Emerging Forces (NEFOs) were described as still relevant in a world in which "neocolonialism" exists in the form of economic domination. ${ }^{130}$ Sukarno's ideological legacy, though ambiguous, is still alive.

Regardless of ideological relevance, Sukarno was consistently referred to as a resolute hero who struggled valiantly against the Dutch and as an ideologue who founded the Pancasila. No mention was ever made of Rosihan Anwar's and Nugroho Notosusanto's previous claims to the contrary, and so it would appear that critiques of that sort have been entirely discounted. Sukarno was never accused of being a Communist during this debate; even Amirmachmud, one of the few who maintained that Sukarno was involved in G-30-S, said that Sukarno was not Communist. ${ }^{131}$ So it would seem that Soegiarso Soerojo's effort, too, has been defeated and ignored. Are Mochtar Lubis's comments destined to suffer the same fate?

126 See "Sukarno's Daughter Hurt By White Paper" in The Jakarta Post, October 6, 1994; "Manai Proud of Controversial Book on Sukarno," in The Jakarta Post, September 30, 1994; "Bung Karno Setuju PKI Dibubarkan," in Sinar, October 3, 1994; and "Banyak Pemikiran dan Gagasannya Yang Masih Relevan, in Merdeka, Minggu Kedua, October 1994.

127 See "Bung Karno Versi Buku Putih," in Sinar, June 20, 1994; "Bung Karno Sukar Terima Bantahan," and "Kiprah Bapak Ideologi" in Sinar, October 3, 1994; "Ada Proses Rehabilitasi Bung Karno," in Sinar, October 10, 1994.

128 "Bung Karno Tidak Terlibat!" Tiara, September 25, 1994, p. 32.

129 M. Amien Rais, "Buku Putih," Merdeka, October 10, 1994, p. 16. Mochtar Lubis believed that Sukarno's NASAKOM philosophy, which tried to unite nationalism, religion and Communism, was like mixing fire and water and thus bound to fail. However, as Amien Rais suggested in his interview with Merdeka, an ideology must be evaluated within its historical context. Today, it would seem that Communism, nationalism and Islam are innately incompatible, but when Sukarno first developed this ideology in 1927, it was entirely possible that such cooperation could have succeeded. The Communist uprisings in Indonesia in 1926-27, for example, took place in heavily Muslim areas, suggesting that at the time there was overlap between Communists and Muslims. Furthermore, Sukarno, as a "statistical Muslim," had every reason to believe that religion and Communism could be subordinated to the overriding goal of nationalism.

130 "Ada Proces Rehabilitasi Bung Karno," Sinar,October 10, 1994, p. 21; "Banyak Pemikiran dan Gagasannya Yang Masih Relevan," Merdeka, Minggu Kedua, October 1994, p. 1.

131 "Amirmachmud Tentang Sukarno," Kompas, October 1, 1994, p. 13. 


\section{Conclusion}

When President Soeharto declared a "New Order" after taking control of the government in 1966, he did so to distance himself from the chaos and strife of the Sukarno era. His leadership was to be a "new" leadership which would lead Indonesia into the future. But in calling his regime the New Order, he was by design establishing himself in terms of something else; the very nature of a New Order is that it supersedes something old. The Old Order thus becomes a reference point for the New Order; what was in the Old Order is no longer in the New. Soeharto had established a regime that was fated to be juxtaposed psychologically with the one it overthrew.

This comparative phenomenon is reinforced by the reality of Indonesia's political development; since gaining independence in 1945, Indonesia has been guided by only two top leaders. And the two men who have held that job could hardly have been more different. In just about every category one can think of, Soeharto is the stylistic and ideological opposite of his predecessor. While in the early years of the New Order, such comparisons may have favored Soeharto's stabilizing rule, it has become clear that the New Order/Old Order distinction has not continued to work in Soeharto's favor.

In response to shifting perceptions, Soeharto has taken different approaches toward Sukarno. He has quietly encouraged efforts to discredit Sukarno and worked to control the strength of his legacy. When this tactic has proven unfruitful, Soeharto has tried to co-opt his predecessor's popularity by presenting himself as part of the continuum that Sukarno's leadership set into motion. This alternation between containment and coöptation has found its ultimate expression in Soeharto's mikul dhuwur mendhem jero philosophy; he can appear chivalrous in his calls to honor Sukarno while limiting the former president's mythological stature by implying that he had made mistakes.

This attitude has not been successful in containing Sukarno's posthumous power. The nostalgic longing for a romantic and charismatic figure like Sukarno persists among his admirers. Sukarno's long dramatic speeches at the UN and his audacious attitude vis-a-vis the West-telling the United States to "go to hell with your aid" - were a source of pride for the new nation of Indonesia. The memory of this glory and grandeur-however selectivehas proven a potent force in New Order Indonesia. Sukarno, who had often incorporated wayang imagery into the text of his mesmerizing speeches, is widely held to have thought and moved in the world of the wayang himself. He was said to have associated himself with the character Bima, a figure who is considered contemptuous of established authority and prepared to rebuke even the gods, and that he frequently saw his own life in the wayang's dramatic, uncompromising terms. ${ }^{132}$ Perhaps it is this quality people miss in the cold and calculating New Order-the passion, nobility, and drama of the past. The heroes of the wayang don't need money to sustain them; they're concerned with the more lofty pursuits of glory and honor. And so it was with President Sukarno, who believed in causes and struggles, not computations and proposals, who promised to lead "the revolution of mankind" and "build the world anew."

For many Indonesians who lived through Sukarno's era, something has indeed been lost in the New Order. But it is among those who are not old enough to have felt Sukarno's enormous presence-and who therefore did not experience the chaos and strife of his time-that Sukarno's myth has become the most powerful. A new generation of students and intellectuals who are increasingly dissatisfied with the restrictions of the New Order

${ }^{132}$ Legge, Sukarno: A Biography, p. 23. 
have looked to the past for inspiration and guidance and found the towering figure of Sukarno to embody their discontent. Feeling constricted in the age of development, they, too, seem to be longing for a romantic, flamboyant figure. But what seems to attract the masses and the young people is not Bung Karno per se but what he has come to symbolize: opposition to the New Order. After all, it was Soeharto who defined his regime against that of Sukarno's. The utility of that distinction has not been lost on his critics.

Sukarno's star has not risen unchallenged; his detractors have included government representatives, such as Nugroho Notosusanto, as well as writers influenced by more personal antipathies, such as Rosihan Anwar and Mochtar Lubis. But each effort to diminish Sukarno's strength seems only to have made the myth more powerful. Sukarno continues to live in history, and it is unlikely that he will cease to do so anytime soon. Megawati, Sukarno's daughter, has taken up the political torch and thus renewed her father's visibility and popularity. But even without the aid of his children, Sukarno will continue to be part of the national debate. This must partly be attributed to the powerful legacy of G-30-S. As a key event in Indonesian history, G-30-S will always be open to interpretation; as a human tragedy laden with traumatic experiences, it will be remembered in Indonesia with much bitterness and anger. Sukarno's role in those events, as they can no longer be definitively proven, will always be a cause for controversy.

In broader terms, however, it would seem that any discussion of the problems relating to the structure of government, to the Constitution, to the level of prosperity of Indonesian society, and to the openness of creative thought will necessarily include a discussion of Sukarno. Seventy-three-year-old President Soeharto cannot rule forever, and Indonesia has begun to brace itself for its first succession in what will have been at least thirty years. Given the unique historical circumstances in which Sukarno was forced out of office, the upcoming elections represent the first potentially peaceful, constitutional transfer of power that the Indonesian nation has ever known. It is no coincidence that articles debating Manai Sophiaan and the Buku Putih in October 1994 were published alongside articles discussing the upcoming elections in 1997. Who will run for President? What will be the military's role? Will another party be created? Will Soeharto really step aside?

If Soeharto runs again, as all signs seem to indicate, he will undoubtedly move once more to try to neutralize both Megawati and Bung Karno before 1997. Mega has, in fact, been trying desperately to fend off government efforts to topple her from within the PDI, while Sukarno's legacy is once again under attack from the State Secretariat. On May 29, 1995, Minister of the State Secretariat Moerdiono presented President Soeharto with the third edition of Risalah Sidang Badan Penyelidik Usaha-Usaha Persiapan Kemerdekaan Indonesia (BPUPKI) Panitia Persiapan Kemerdekaan Indonesia (PPKI) (Report of the Session of the Body for the Investigation of the Preparation of Indonesian Independence: The Committee for the Preparation of Indonesian Independence). Like Nugroho Notosusanto's work in 1981, this book rehashes the issue of who was the first to formulate the Pancasila. Though Moerdiono claims that the book neither tries to alter history nor discredit Sukarno, ${ }^{133}$ it is clear that it once again attempts to remove Sukarno from his privileged and incomparable position as the creator of the sacred Five Principles. The fanfare surrounding the book's release and the efforts to place Sukarno as just one of a whole group of founding fathers-only seven months after the State Secretariat released the Buku Putih-can only be understood against the backdrop of the looming elections. If the convoluted history of Indonesia's struggle to

133 "Tak Ingin Mengubah Sejarah," Gatra, June 10, 1995, p. 26. 
come to terms with Sukarno is any guide, one can be sure that this latest work will not be the last word.

\section{Bibliographic Note}

The bulk of the preceding paper uses the Indonesian press for source material. For the 1994 portion of my analysis, I followed the polemic daily in the Indonesian press, consulting several Indonesian dailies-Kompas, Merdeka, Republika, Suara Merdeka and The Jakarta Postso as to account for different perspectives. For the Soegiarso Soerojo debate, the PDI issues, and the Manai Sophiaan/Buku Putih controversies, I relied heavily on weekly magazines such as Tempo, Editor, Forum Keadilan and (after Tempo and Editor were banned) Sinar and Gatra. The Buku Putih, Soegiarso Soerojo's Siapa Menabur Angin Akan Menuai Badai, and Manai Sophiaan's Kehormatan Bagi Yang Berhak were crucial elements of my research.

I was fortunate that other scholars had already dealt with the early periods of Sukarno's rehabilitation; two of the most useful sources were written by Pierre Labrousse ("The Second Life of Bung Karno: Analyzing the Myth (1978-1981)," in Indonesia No. 57, April 1994) and Oey Hong Lee ("The Sukarno Controversies of 1980/81," The University of Hull/Centre for Southeast Asian Studies, Occasional Paper No. 4, 1982). Both of these analyses are referred to extensively in the appropriate sections. Based on the citations in these studies, I was able to go back and look at specific debates in newspapers such as Kompas and Sinar Harapan during the period in question.

For background information on Sukarno, I consulted J.D. Legge's, Sukarno: A Political Biography (Australia: Allen \& Unwin, 1984). Clifford Geertz's essay, "The Politics of Meaning" in The Interpretation of Cultures (USA: Basic Books, 1973), provides useful insights into the effects of the 1965 coup. For Soeharto's reactions to Sukarno, I used his autobiography, Soeharto: My Thoughts Words and Deeds (Jakarta: P. T. Citra Lamtoro Gung Persada, 1991). Finally, O.G. Roeder and Mahiddin Mahmud's Who's Who in Indonesia (Singapore: Gunug Agung, 1980) was helpful in figuring out just who was contributing to all of the polemics and why. 
